\title{
REWRITING THE LAW OF RESALE PRICE MAINTENANCE: THE KODAK DECISION AND TRANSACTION COST ECONOMICS
}

\author{
FRANK X. TANEY $†$
}

\section{INTRODUCTION}

On June 8, 1992, the Supreme Court decided Eastman Kodak Co. v. Image Technical Services. ${ }^{1}$ The decision quickly sent a shudder through the world of antitrust, ${ }^{2}$ and has been both praised ${ }^{3}$ and vehemently condemned. ${ }^{4}$ Much has already been written about Kodak's potential for changing the antitrust landscape in terms of franchise relationships, ${ }^{5}$ summary judgment in antitrust cases, ${ }^{6}$ implementation of the "rule of reason" test, ${ }^{7}$ antitrust analysis of

† B.A. 1992, Drew University; J.D. Candidate 1995, University of Pennsylvania. First and foremost, I would like to thank Mom, Dad, and Sheila for their unwavering and indispensable support in this and other endeavors. I would also like to thank the members of the Law Review, especially Jaimy Levine, Andrew Schiesl, and Jennifer Wolgemuth, for their editorial comments and assistance.

${ }^{1} 112$ S. Ct. 2072 (1992).

2 In an address before the 13th Annual Seminar on Distribution and Dealer Termination, held only three days after the Kodak decision, Joseph Kattan noted that Kodak was "already being interpreted as setting out the limits of judicial acceptance of economic theory in antitrust cases." Joseph Kattan, Economic Theory as a Substitute for Evidence in Antitrust: The Difficulty of Erecting Rules of Law on Theory After Kodak, ANTITRUST L. \& ECON. REV., No. 3 1991, at 13, 14. At the time, Mr. Kattan was the Assistant Director for Policy and Evaluation, Bureau of Competition, Federal Trade Commission.

${ }^{3}$ See, e.g., Gordon B. Spivack \& Carolyn T. Ellis, Kodak: Enlightened Antitrust Analysis and Traditional Tying Law, 62 ANTrTRUST L.J. 203, 206 (1993) (praising the Court's balanced decision to change the analytical analysis in antitrust cases without "a wholesale rejection of economic theory").

4 See, e.g., Michael S. Jacobs, Market Power Through Imperfect Information: The Staggering Implications of Eastman Kodak Co. v. Image Technical Services and a Modest Proposal for Limiting Them, 52 MD. L. REV. 336, 373 (1993) ("Kodak is arguably the most important antitrust decision of the past twenty years. Unfortunately, it is a disaster.").

${ }^{5}$ See George A. Hay, Is the Glass Half-Empty or Half-Full?: Reflections on the Kodak Case, 62 ANTITRUST L.J. 177, 185-88 (1993) (discussing the potentially "fruitful" applications of the Kodak argument to franchise relationships).

${ }^{6}$ See W.B. Markovits, A Focus on Reality in Antitrust: An Analysis of the Kodak Case, 39 FED. B. NEws \& J. 592, 592-94 (1992) (stating that the Kodak Court radically shifted "back to a more restrictive standard for antitrust summary judgment").

${ }^{7}$ See Jacobs, supra note 4 , at 340 . 
tie-in arrangements, ${ }^{8}$ and the role of Chicago School economics in antitrust jurisprudence. ${ }^{9}$

The purpose of this Comment, however, is to demonstrate and predict how the Kodak decision and the Court's apparent acceptance of the transaction cost economics perspective $\mathrm{e}^{\mathrm{10}}$ could lead to a change in courts' treatment of resale price maintenance (RPM). ${ }^{11}$ RPM refers to arrangements by which a manufacturer may attempt to control the final retail price charged for its products by retailers or distributors. ${ }^{12}$ As most commonly employed by manufacturers, this practice involves a price floor ${ }^{13}$ Although RPM is currently illegal per se, ${ }^{14}$ this Comment, using the same transaction cost methodology employed by the Supreme Court in Kodak, advances a justification for RPM as a tool for market entry.

Part I of this Comment traces the development of the antitrust treatment of RPM and the problems courts have faced in specifying what varieties of price maintenance activities violate the antitrust

${ }^{8}$ See generally Warren S. Grimes, Antitrust Tie-In Analysis After Kodak: Understanding the Role of Market Imperfections, 62 ANTITRUST L.J. 263 (1994) (examining the law and theory of tie-ins after Kodak).

${ }^{9}$ See, e.g., Spivack \& Ellis, supra note 3, at 214-16 (describing the tenets of the Chicago School rejected by Kodak). See generally Ronald S. Katz \& Janet S. Arnold, Eastman Kodak v. ITS: The Downfall of the Chicago School, COMPUTER LAW., July 1992, at 1 (describing the Kodak Court's rejection of the three major tenets of Chicago School theory).

${ }^{10}$ Transaction cost economics has also been referred to as post-Chicago economics and as information economics. See, e.g., Robert H. Lande, Chicago Takes It on the Chin: Imperfect Information Could Play a Crucial Role in the Post-Kodak World, 62 ANTITRUST L.J. 193, 197 (1993) ("Kodak thus dramatically crystallizes many of the differences between Chicago School and post-Chicago School antitrust analysis and suggests that, at least for now, the post-Chicago School has the opportunity to advance."). The basic elements of the transaction cost economics approach will be discussed infra part II.B.

11 This Comment will refer to both "RPM" and "vertical price restraints," and for the purpose of this Comment, the two terms are interchangeable.

${ }_{12}$ In a world without antitrust regulation, a manufacturer might require, explicitly and contractually, that a retailer distributing the manufacturer's products sell at or above a specific price, or it might simply announce its pricing policy and refuse to deal with distributors who fail to comply with the policy. Further, in its efforts to determine which retailers are complying with its policy, the manufacturer might simply choose to rely upon its own monitoring efforts, or it might choose to solicit reports from the retailers' competitors. Antitrust regulation impacts the methods manufacturers use in attempting to maintain prices. See infra part I.

13 This Comment is concerned only with minimum resale price maintenance, and not with maximum resale price maintenance, which involves attempts by manufacturers to set ceilings on resale prices.

${ }^{14}$ For a discussion of the per se approach, see infra notes 20-22 and accompanying text. 
laws. Part I also demonstrates how the current antitrust treatment of RPM, the cartel paradigm, which assumes that RPM arrangements are anticompetitive, is unsatisfactory in several respects.

Part II presents two differing conceptions of economics and antitrust-the Chicago School and transaction cost economics-upon which procompetitive justifications for RPM could be built. This Part outlines the fundamental features and differences between these two paradigms. Part III explores the Chicago School's previous attempt to justify RPM-the free-rider hypothesis. Part III also examines why the free-rider hypothesis failed to gain acceptance.

Part IV predicts that transaction cost economics can succeed in encouraging acceptance of RPM where the Chicago School failed. The discussion first examines the Kodak decision, focusing on how the court clears the way for an increased reliance on transaction cost methodology in antitrust. This Part then advances a transaction-cost-based justification for RPM that is particularly well-situated for acceptance by the courts: RPM as a tool for market entry. This Comment concludes with a brief examination of political and economic factors that might affect acceptance of a transaction-costbased justification of RPM as a tool for market entry.

\section{A BRIEF History OF RPM}

\section{A. The Cartel Paradigm Becomes Entrenched}

\section{Per Se Illegality of RPM}

Section 1 of the Sherman Antitrust Act of $1890^{15}$ provides that "[e]very contract, combination in the form of trust or otherwise, or conspiracy, in restraint of trade or commerce among the several States, or with foreign nations, is declared to be illegal."16 Courts have consistently construed this language to prohibit only "unreasonable" restraints of trade. ${ }^{17}$ Yet as the authors of the Sherman

${ }^{15} 15$ U.S.C. $\S \S 1-7$ (1988).

${ }^{16} I d . \S 1$.

${ }^{17}$ See, e.g., National Collegiate Athletic Ass'n v. Board of Regents, 468 U.S. 85, 98 (1984) (noting that "the Sherman Act was intended to prohibit only unreasonable restraints of trade"); Standard Oil Co. v. United States, 221 U.S. 1, 60 (1911) (explaining that common law looked to "standard[s] of reason" to determine whether the statute had been violated). This judicial construction evolved into, and has become known as, the "rule of reason" standard. For a discussion of the origins and subsequent application of the rule of reason standard, see infra notes 32-34 and 
Act suspected, and as the courts have often found, defining the precise boundaries of the Act's coverage often proves to be difficult. $^{18}$

Despite the conceptual difficulties inherent in determining which practices constitute "unreasonable" restraints of trade, the Supreme Court settled on an apparently clear-cut and easily administrable rule of law for cases of RPM: per se illegality. ${ }^{19}$ Under the per se approach, once a court identifies a given course of conduct or restraint as falling within a proscribed category, it finds a violation of the Sherman Act, regardless of the actual effects of the conduct and despite any benefits that the conduct produces. ${ }^{20}$ Courts purportedly reserve per se illegality for privately created market restraints that "lack ... any redeeming virtue" and that have the most "pernicious effect on competition."21 Courts justify per se rules as labor saving, since a court applying a per se rule need not make a detailed inquiry into the effects of the conduct at issue. ${ }^{22}$

accompanying text. In certain cases, however, courts deviate from the rule of reason standard. See infra notes 20-22 (detailing the per se rule).

${ }^{18}$ Witness Senator Sherman's oft-quoted statement discussing Congress's decision to let the courts flesh out the meaning of the Act:

I admit that it is difficult to define in legal language the precise line between lawful and unlawful combinations. ... All that we, as lawmakers, can do is to declare general principles, and we can be assured that the courts will apply them so as to carry out the meaning of the law, as the courts . . . have done for centuries.

21 CONG: REC. 2460 (1890).

Commentators have attributed Congress's reluctance to draft a more specific statute to fears that more specific prohibitions against particular business forms would be both easily circumvented and likely to become obsolete. See, e.g., HaNS B. THORELl, ThE FEDERAL ANTITRUST POLICY 229 (1955) (stating that "detailed legislation would run a serious risk of becoming obsolete in a very short time in the dynamics of economic life and its institutions").

${ }^{19}$ See Dr. Miles Medical Co. v. John D. Park \& Sons Co., 220 U.S. 373, 408 (1911) (holding that agreements among dealers designed to fix prices are "injurious to the public interest and void").

${ }^{20}$ Thus, the Dr. Miles Medical Court stated that because the manufacturer's program fell "within the principle which condemns contracts of this class. ... [n]o distinction can properly be made by reason of the particular character of the commodity in question." Id.

${ }^{21}$ Northern Pac. Ry. v. United States, 356 U.S. 1, 5 (1958); see also Northwest Wholesale Stationers, Inc. v. Pacific Stationery \& Printing Co., 472 U.S. 284, 289-90 (1985) ("The decision to apply the per se rule turns on "whether the practice facially appears to be one that would always or almost always tend to restrict competition and decrease output ... . or instead one designed to "increase economic efficiency and render markets more, rather than less, competitive."' (citations omitted)).

${ }^{22}$ See Arizona v. Maricopa County Medical Soc'y, 457 U.S. 332, 351 (1982) 
In Dr. Miles Medical, the Court relied on two arguments in applying the per se illegality rule to RPM. First, it adopted the common-law rule that RPM agreements were unreasonable restraints on alienation. ${ }^{23}$ The court cited Lord Coke for the proposition that "if a man be possessed of any ... chattel ... and give his whole interest of property therein, upon condition that the donee or vendee shall not alien the same, the same is void, because his whole interest and property is out of him, so as he hath no possibility of reverter." 24 The Court viewed the defendant's attempts to control the retail prices of its goods as analogous to the situation discussed by Lord Coke. ${ }^{25}$ Second, the Dr. Miles Medical Court criticized the defendant's RPM arrangements as being "injurious to the public interest," and as "having for their sole purpose the destruction of competition and the fixing of prices. ${ }^{26}$ In making this second argument, the Court refused to entertain the notion that an RPM program could involve either procompetitive purposes or effects. ${ }^{27}$ Instead, the Court took the view that RPM was invariably a tool of either retailer ${ }^{28}$ or manufacturer ${ }^{29}$ cartels

(rejecting "the argument that the per se rule must be justified for every industry that has not been subject to significant antitrust litigation").

${ }^{23}$ See Dr. Miles Medical, 220 U.S. at 404-05 ("The right of alienation is one of the essential incidents of a right of general property in movables, and restraints upon alienation have been generally regarded as obnoxious to public policy." (citation omitted)).

${ }^{24} I d$. (citations omitted).

25 See $i d$. at 405.

${ }^{26}$ Id. at 408. This line of reasoning was also adopted in Boston Store v. American Graphophone Co., 246 U.S. 8, 27 (1918) (holding that "a patentee, in connection with the act of delivering his patented article to another for gross consideration then received, [cannot] lawfully reserve by contract a part of his monopoly right to sell").

${ }^{27}$ This anticompetitive explanation of RPM arrangements contrasts directly with both the Chicago School and transaction cost justifications of RPM. See infra parts III-IV (discussing Chicago School and transaction cost justifications of RPM); see also Benjamin Klein \& Kevin M. Murphy, Vertical Restraints as Contract Enforcement Mechanisms, 31 J.L. \& ECON. 265, 280 n.20 (1988) (discussing the differences between positive explanations of RPM arrangements and the "collusive" theory of RPM).

${ }^{28}$ The paradigmatic retailer cartel situation involves a smallish manufacturer pressured into maintaining prices by an inefficient group (or cartel) of retailers. See, e.g., Ward S. Bowman, Jr., The Prerequisites and Effects of Resale Price Maintenance, 22 U. CHI. L. REv. 825, 848 (1955) (explaining that manufacturers are likely to acquiesce to the demands of a retailer cartel when the prevailing conditions involve dealers' or retailers' "monopoly and competing manufacturers"). If the retailers do not account for a large percentage of the manufacturer's wholesale market, it is unlikely that they would be able to exert meaningful pressure on the manufacturer. See id. at 847 ("Solidarity on the part of [small] retailers was essential, and this meant . . . the power to effectively boycott a manufacturer's goods.").

${ }^{29}$ The manufacturer cartel scenario involves an attempt by a group of manufac- 
that desired a mechanism to keep prices artificially high and to control competition. This is the paradigmatic cartel explanation of RPM which has been accepted consistently in modern cases, ${ }^{30}$ and continues to dominate the government's current enforcement patterns and attitudes toward RPM. ${ }^{31}$

The per se approach, both as generally applied and as adopted in the area of RPM, contrasts directly with the other main judicial tool of inquiry in antitrust cases: the rule of reason approach. The rule of reason inquiry allows defendants to justify their actions based on procompetitive effects. ${ }^{32}$ A fact-finder applying the rule of reason "weighs all the circumstances of a case in deciding whether a restrictive practice should be prohibited as imposing an unreasonable restraint on competition. ${ }^{33}$ As the rule of reason test has evolved, courts have engaged in detailed analyses of the market share possessed by particular companies, the concentration of particular industries, the ability of companies to affect prices and outputs in relevant markets, and the definition of relevant markets. $^{34}$

turers to restrict output and reap monopoly profits. The cartel members are motivated by the fear that discounting retailers may put pressure on manufacturers to cut wholesale prices in order to avoid losing market share. See id. at 838-39. The RPM arrangement, with its resultant terminations for price cutting, could serve to preserve the cartel. See id. at 849.

${ }^{30}$ See, for example, infra part I.B for a discussion of Continental TV, Inc. v. GTE Sylvania, Inc., 433 U.S. 36 (1977), and its reliance on the cartel paradigm.

${ }^{31}$ See Kattan, supra note 2, at 15 (noting that "resale price maintenance continues to be an area of activity for [Federal Trade] Commission staff, particularly cases that focus on the possibility of concerted dealer coercion to force suppliers to impose the restraint"). Kattan further recognizes that "these potential dealer cartel cases present the clearest cases from an economic standpoint." Id.

32 The rule of reason standard was first articulated by Justice Peckham in United States v. Trans-Missouri Freight Ass'n, 166 U.S. 290 (1897), and most famously by Chief Justice White in Standard Oil Co. v. United States, 221 U.S. 1 (1911), and United States v. American Tobacco Co., 221 U.S. 106 (1911). See Robert H. Bork, The Rule of Reason and the Per Se Concept: Price Fixing and Market Division, 74 YALE L.J. $775,785-96$ (1965) (analyzing the Justices' application of the rule of reason).

${ }^{33}$ Sylvania, 433 U.S. at 49.

${ }^{34}$ See, e.g., F.M. Scherer, Merger in the Petroleum Industry: The Mobil-Marathon Case, in ThE ANTITRUST Revolution 19 (John E. Kwoka, Jr. \& Lawrence J. White eds., 1989) (outlining the intricacies of applying the rule of reason test). 


\section{Subsequent Problems with Application of the Per Se Rule}

At one conceptual level, application of the per se rule against RPM is straightforward: if a company "agrees" with other market participants to maintain prices, the company-and the other participants-have violated the Sherman Act. A major source of difficulty arises, however, when a court must determine if the manufacturer, through its actions, has entered into an actual RPM "agreement" with other market participants. Because section 1 of the Sherman Act prohibits only contracts, combinations, and conspiracies ${ }^{35}$ which restrain trade, "it is not unlawful for a single firm, acting alone, to fix prices. Fixing prices is illegal only when there are [at least] two parties and an agreement." ${ }^{\text {36 }}$ Given this statutory backdrop, courts attempting to apply the per se rule to RPM have faced the unenviable task of defining the precise meaning of the term "agreement" and the permissible limits on a manufacturer's efforts to maintain prices. The courts have struggled with this task, and it is not at all clear that their solutions are well-conceived. In addition, as the following discussion illustrates, legislative efforts to resolve the problems reflect congressional confusion as to the proper scope of the Sherman Act with regard to RPM.

In United States v. Colgate $\mathcal{E}^{2} \mathrm{Co} .{ }^{37}$ the Supreme Court created a significant exception to the per se illegality rule established by $D r$. Miles Medical. ${ }^{38}$ In Colgate, the Court held that a manufacturer's unilateral decision that it would not deal with stores that undercut its posted retail prices did not run afoul of the Sherman Act. ${ }^{39}$ The Court stressed the fact that the record lacked any evidence indicating that Colgate had entered into any contracts with dealers "whereby ... the manufacturer, and [the retailers], bound themselves to enhance and maintain prices." 40 According to the Court, this holding merely affirmed the principle that a "manufacturer . . . can sell to whom[ever] he pleases." ${ }^{41}$

${ }^{35}$ See 15 U.S.C. $\$ 1$.

${ }^{36} \mathrm{Jean}$ W. Burns, Rethinking the "Agreement" Element in Vertical Antitmust Restraints, 51 OHIO ST. L.J. 1, 4 (1990) (footnotes omitted).

${ }^{37} 250$ U.S. 300 (1919).

${ }^{38} 220$ U.S. 373.

${ }^{39}$ See 250 U.S. at 307.

${ }^{10} I d$. at 305 .

${ }^{11} I d$. at 307 (quoting United States v. Trans-Missouri Freight Ass'n, 166 U.S. 290, $320(1897))$. 
Thus, after Colgate, the critical inquiry in the area of RPM was whether the manufacturer maintained prices by way of an "agreement" between itself and a retailer or other downstream supplier. ${ }^{42}$ Although the Colgate decision clearly had the potential to gut the per se illegality rule, the Court subsequently eased plaintiffs' burdens by inferring the existence of RPM agreements from a manufacturer's "course of dealing." 43

In United States v. Parke, Davis $\mathcal{E}$ Co., ${ }^{44}$ the Supreme Court essentially eliminated the practical value that the Colgate exception held for manufacturers. In Parke, Davis, the Court ruled that a manufacturer may not threaten, intimidate, warn or use "other means that affect adherence to his resale prices. ${ }^{45}$ The company violated the Court's formulation by supplying the names of pricecutting retailers to wholesalers, who then refused to deal with the retailers, and by advocating adherence to its RPM program to various retailers and wholesalers. ${ }^{46}$ After Parke, Davis a manufacturer could do no more than publish a list of desired prices and refuse to deal with noncomplying retailers. ${ }^{47}$ Subsequent applications of the Parke, Davis decision forced manufacturers to choose their words and actions very carefully to avoid liability under the Sherman Act for their RPM programs. ${ }^{48}$

12 This development was unfortunate in the sense that, as a result of the Colgatebased distinction between "unilateral" RPM and RPM arrangements enforced by contracts or other agreements, courts did not develop a more thoughtful analysis of RPM or other vertical price restraints, as they did for nonprice vertical restraints in recent years. See William F. Baxter, The Viability of Vertical Restraints Doctrine, 75 CAL. L. REV. 933, 933 (1987) (discussing the "anti-intellectual" development of the RPM doctrine).

${ }^{13}$ Frey \& Son, Inc. v. Cudahy Packing Co., 256 U.S. 208, 210 (1921) (stating that "the essential agreement, combination, or conspiracy might be implied from a course of dealing"); see also United States v. A. Schrader's Son, Inc., 252 U.S. 85, 97 (1920) ("The tacit acquiescence of the wholesalers and retailers in the prices thus fixed is the equivalent for all practical purposes of an express agreement.").

44362 U.S. 29 (1960).

${ }^{45} \mathrm{Id}$. at 44.

${ }^{46}$ See id. at $32-36$.

47 "When the manufacturer's actions, as here, go beyond mere announcement of his policy and the simple refusal to deal, and he employs other means which affect adherence to his resale prices, ... he has put together a combination in violation of the Sherman Act." Id. at 44.

${ }^{48}$ See, e.g., United States v. General Motors Corp., 384 U.S. 127, 142-43 (1966) (stating that "it has long been settled that explicit agreement is not a necessary part of a Sherman Act conspiracy”); Simpson v. Union Oil Co., 377 U.S. 13, 24 (1964) (holding that "resale price maintenance through the . . . coercive type of 'consignment' agreement is illegal under the antitrust laws"). 
Judicial intolerance of vertical market restraints reached its zenith with United States $v$. Amold, Schwinn $\mathcal{E}^{\circ} \mathrm{Co}^{49}$ In Schwinn, the Supreme Court used a per se analysis ${ }^{50}$ to invalidate Schwinn's use of a complex set of exclusive territories and distributorships, even though "competition made necessary the challenged program ... [which] was justified by, and went no further than required by, competitive pressures." ${ }^{51}$ The Court admitted that the "net effect [of the Schwinn policy was] to preserve and not to damage competition. ${ }^{52}$ While the Schwinn decision did not explicitly alter the existing law regarding RPM, the Court's disregard for the admittedly procompetitive effects of Schwinn's nonprice vertical restraints did not bode well for the prospects of future thoughtful judicial analysis of RPM.

In the legislative arena, early congressional attitudes toward RPM did not completely reflect the courts' hostility. Although opponents of RPM defeated all attempts at nationwide legalization of RPM between 1914 and $1936,,^{53}$ in 1937 Congress passed the Miller-Tydings Enabling Amendment, ${ }^{54}$ which allowed manufactur-

In addition, the Federal Trade Commission (FTC) investigation of Lenox, Incorporated, a producer of fine china, provides an interesting case study of the extent to which the Colgate exception has been narrowed. In 1966, the FTC subjected Lenox to an investigation after a complaint from a terminated dealer. At issue was not the existence of an RPM program, but "whether Lenox's enforcement of it (and other restrictions) by terminating noncooperating dealers fell outside the protection of the peculiar boundaries demarcated by Colgate and Parke, Davis." Victor Goldberg, Enforcing Resale Price Maintenance: The FTC Investigation of Lenox, 18 AM. BuS. L.J. 225,225 (1980). The FTC's investigation culminated in a consent order entered with approval of the Second Circuit Court of Appeals. The final order prohibited Lenox from requiring RPM of dealers through franchise agreements; requiring RPM as a condition of buying Lenox products; soliciting dealer policing of RPM or acting on such reports by threatening or actually terminating dealers; coercing dealers in any way to maintain resale prices; using any cooperative means to establish a system of RPM; selling to dealers at a markdown from resale for three years (appealable after two years); prohibiting dealers from transshipping; and publishing resale price lists for three years (appealable after two years). See id. at 257-58.

19388 U.S. 365 (1967), overruled in part by Continental T.V., Inc. v. GTE Sylvania, Inc., 433 U.S. 36 (1977).

${ }^{50}$ Schwinn overruled earlier decisions such as White Motor Co. v. United States, 372 U.S. 253 (1963), which had applied a rule of reason standard to nonprice vertical restraints. For a discussion of the rule of reason standard, see supra notes 32-34 and accompanying text.

${ }^{51}$ Schwinn, 388 U.S. at 382.

52 Id.

${ }^{35}$ Various industry groups, including manufacturers of consumer goods and pharmacy retailers, were the primary advocates of RPM at that time. See S.C. Hollander, The United States of America, in RESAle PrICE MAINTENANCE 65, 68 (B.S. Yamey ed., 1966).

54 District of Columbia Revenue Act of 1937, Pub. L. No. 75-314, 50 Stat. 673, 
ers to maintain retail prices in states that had previously enacted "fair trade" laws. ${ }^{55}$ The Amendment provided that a manufacturer could use RPM only if its product was in free and open competition with other similar goods. ${ }^{56}$ Many states exhibited an even greater degree of tolerance toward RPM by subsequently enacting "nonsigners' clauses." ${ }^{57}$ Such clauses provided that a manufacturer's RPM agreement with one dealer bound all others in the state, regardless of whether they agreed to the RPM. ${ }^{58}$ The McGuire Act of $1952^{59}$ subsequently validated these nonsigners' clauses.

Through the 1960s and early. 1970s, however, congressional opinion gradually turned against RPM, culminating in the passage of the Consumer Goods Pricing Act of $1975,{ }^{60}$ which repealed the Miller-Tydings Enabling Amendment. Once again, Congress made the most practical types of RPM programs illegal. Unilaterally imposed and maintained RPM programs were still legal under the Colgate doctrine, but only in the withered form allowed by Parke, Davis and its progeny. ${ }^{61}$

\section{B. Conflicting Signals on the Treatment of RPM: From Sylvania to the Present}

From the late 1970s onward, Congress, the courts, and the government's antitrust enforcement agencies seemed to decide to work at cross purposes. As the following discussion indicates, the courts have purported to incorporate economic analysis into antitrust jurisprudence, but have been only partially successful. During this time courts have also applied a per se rule to RPM

693-94, repealed by Consumer Goods Pricing Act of 1975, Pub. L. No. 94-145, 89 Stat. 801 (amending 15 U.S.C. $\$ \S 1,45$ (a) (1890)).

${ }^{55}$ See id. at 693; see also Hollander, supra note 53, at 68 (detailing how the MillerTydings Enabling Amendment lifted the Sherman Act prohibition on vertical price control if the state in which the merchandise was finally retailed allowed RPM). Beginning in 1933, 14 states passed laws legalizing RPM. However, the laws applied only to goods manufactured, distributed, and retailed in the same state and, as a result, had limited impact. See id.

${ }^{56}$ See 50 Stat. at $693-94$.

${ }^{57}$ Hollander notes that "many of the states simply adopted verbatim the California model statute which the National Association favoured," and which contained the “crucial 'non-signers' clause." Hollander, supra note 53, at 69 (footnote omitted).

${ }^{58}$ See id.

${ }^{59}$ Pub. L. No. 82-542, 66 Stat. 631.

${ }^{60}$ Pub. L. No. 94-145, 89 Stat. 801 (amending 15 U.S.C. $\$ 1$ 1, 45(a) (1890)).

${ }^{61}$ See supra notes $44-48$ and accompanying text (discussing the Parke, Davis decision and its subsequent expansion). 
programs, but have considerably narrowed the definition of RPM. Government agencies have become more tolerant of vertical restraints in general, while Congress has grown increasingly hostile toward RPM.

\section{Sylvania and the Ascendancy of Economics in Antitrust}

The tide of judicial hostility toward RPM appeared to turn in 1977, when the Supreme Court overruled Schwinn ${ }^{62}$ in Continental T.V., Inc. v. GTE Sylvania, Inc. ${ }^{63}$ Sylvania re-established the rule of reason standard as governing nonprice vertical restraints. ${ }^{64}$ In upholding GTE Sylvania's use of nonprice vertical restraints, the Sylvania Court recognized that " $[t]$ he market impact of vertical restrictions is complex because of their potential for a simultaneous reduction of intrabrand competition and stimulation of interbrand competition. ${ }^{n 55}$ The Court further noted that "[e]conomists have identified a number of ways in which manufacturers can use such restrictions to compete more effectively against other manufacturers. "66 The Court, noting the considerable scholarly authority in support of its position, concluded that "the per se rule [against vertical nonprice restraints] stated in Schwinn must be overruled. ${ }^{n 67}$ The Court, however, relying on both the cartel paradigm and the passage of the Consumer Goods Pricing Act, stated in dicta that the rule of reason should not apply to vertical price restraints because they "involve significantly different questions of analysis and policy" than nonprice restraints. ${ }^{68}$

Despite the Supreme Court's express unwillingness in Sylvania to overturn the per se rule against RPM, proponents of a rule of reason approach to RPM took comfort in the Sylvania Court's

62 United States v. Arnold Schwinn \& Co., 388 U.S. 365 (1967). See supra notes 49-52 and accompanying text for a discussion of Schwinn.

${ }^{6 s} 433$ U.S. 36 (1977). At issue in the Sylvania case was the legality of certain nonprice restrictions imposed by GTE Sylvania, including location clauses in dealer contracts and limitations on the number of dealers in a given geographical region. See id. at 38-39.

64 See supra note 50 (discussing the White Motor case, in which the Supreme Court applied a rule of reason analysis to a nonprice vertical restraint).

65433 U.S. at 51-52 (citation omitted).

${ }^{66} \mathrm{Id}$. at $54-55$.

${ }^{67}$ Id. at 58.

${ }^{68} I d$. at 51 n.18. The Court contended that RPM arrangements merited per se treatment because such arrangements facilitated cartelization and declared that the repeal of the Miller-Tydings Enabling Act was congressional approval of a per se analysis of vertical price restrictions." Id. 
reliance on economic theory and the general ascendancy of economic analysis in antitrust, ${ }^{69}$ as well as government enforcement agencies' increasingly tolerant views of vertical restraints. ${ }^{70}$ These trends seemed to signal an imminent reconsideration of the per se rule against RPM.

\section{The Redefinition of an RPM "Agreement" and Congressional Response}

In Monsanto Co. v. Spray-Rite Service Corp., ${ }^{71}$ the Supreme Court disappointed those who had hoped for an overruling of the per se rule against RPM. At the same time, the Court imposed a substantial evidentiary burden on plaintiffs attempting to prove the existence of an illegal RPM arrangement. The Monsanto case involved the termination of Spray-Rite, one of Monsanto's herbicide distributors. Spray-Rite alleged that Monsanto's termination decision was prompted by complaints of price cutting made by competing distributors. ${ }^{72}$ In addressing the proper evidentiary standard for finding an illegal RPM program, the Court held that "[p]ermitting an [RPM] agreement to be inferred merely from the

${ }^{69}$ The Sylvania case is regarded as the coming out party for economic analysis in Supreme Court antitrust decisions. See, e.g., Lee E. Preston, Territorial Restraints: GTE Sylvania, in THE ANTTTRUST REVOLUTION, supra note 34, at 273, 283 (noting that the Sylvania Court "insisted that attention be shifted from legal distinctions based upon the passage of title to economic criteria"). Although the Chicago School does not represent the only possible manifestation of economic theory in antitrust law, the rise in the influence of economic theory has been equated with the rise of the Chicago School. See infra part II.A.

${ }^{70}$ By the mid-1980s, the tolerance exhibited by the FTC and the Department of Justice (DOJ) toward vertical restraints aroused the anger of Congress. The DOJ's submission of an amicus curiae brief in Monsanto Co.v. Spray-Rite Service Corp., 465 U.S. 752 (1984), urging the Court to discard the per se rule of Dr. Miles Medical, led Congress to enact a series of gag rules prohibiting the DOJ from using funds to overturn the per se rule against RPM. See, e.g., White House Opposes Authorization of Justice Department with RPM Rider, 52 Antitrust \& Trade Reg. Rep. (BNA) No. 1320 , at 1127 (June 18, 1987) (discussing how the Reagan administration would not support passage of DOJ appropriations legislation unless Congress deleted a provision forbidding funds from being used to overturn the per se rule against RPM). Also, the DOJ's Vertical Restraints Guidelines, issued in 1985, made clear its laissez faire attitude toward vertical restraints, including some uses of vertical price restraints. See U.S. Dep't of Justice Vertical Restraints Guidelines, 50 Fed. Reg. 6263 (1985) (highlighting many procompetitive effects of vertical restraints). These guidelines also drew a legislative reprimand. See H.R.J. Res. 303, 99th Cong., 1st Sess. (1985) (criticizing the DOJ's soft stance against RPM).

${ }^{71} 465$ U.S. 752 (1984).

${ }^{72}$ See id. at 756-59. 
existence of complaints, or even from the fact that termination came about 'in response to' complaints, could deter or penalize perfectly legitimate conduct.... Thus, something more than evidence of complaints is needed [to find an RPM agreement]." The Court held:

[T]here must be evidence that tends to exclude the possibility of independent action by the manufacturer and distributor. That is, there must be direct or circumstantial evidence that reasonably tends to prove that the manufacturer and others had a conscious commitment to a common scheme designed to achieve an unlawful



In applying this standard, the Court found that the evidence, which included what it termed "substantial direct evidence of agreements to maintain prices, ${ }^{75}$ was sufficient to uphold the jury's verdict.

Although Monsanto was nominally a plaintiff's victory, observers concluded that the decision was a victory for future defendants by virtue of the heightened evidentiary requirements it imposed. ${ }^{76}$ Equally significant for the law of vertical price restraints was the fact that the Court sidestepped an opportunity to overturn the per se rule against RPM. ${ }^{77}$ Thus, the Monsanto Court's treatment of the RPM issue left the cartel enforcement explanation and the per se

${ }^{73} I d$. at $763-64$.

${ }^{74} I d$. at 768 .

${ }^{75} I d$. at 765 .

${ }^{76}$ See Frederick R. Warren-Boulton, Resale Price Maintenance Reexamined: Monsanto v. Spray-Rite, in THE ANTITRUST REVOLUTION, supra note 34, at 371, 399 ("II]ronically, Monsanto has come to be considered a substantial victory for the defendant's bar."); see also Sanford M. Litvack, The Future Viability of the Current Antitrust Treatment of Vertical Restraints, 75 CAL. L. REV. 955, 957 (1987) (arguing that the plaintiff's evidentiary burden under Monsanto is very difficult for the jury to comprehend); Mark E. Roszkowski, The Sad Legacy of GTE Sylvania and Its "Rule of Reason": The Dealer Termination Cases and the Demise of Section 1 of the Sherman Act, 22 CONN. L. REV. 129, 173 (1989) ("The approach sanctioned in Monsanto . . . erects an unprecedented and virtually insurmountable evidentiary barrier to plaintiff recovery.").

If Although the DOJ filed an amicus curiae brief urging the Court to apply the rule of reason standard to RPM, the Court refused to consider the issue. Instead, the Court commented, in a footnote:

Certainly in this case we have no occasion to consider the merits of this argument. ... Neither party argued ... [for application of the rule of reason], nor raised the point on appeal. In fact, neither party before this Court presses the argument advanced by amici. We therefore decline to reach the question....

465 U.S. at 762 n.7. 
illegality rule the dominant analytical framework for judicial analysis of RPM. ${ }^{78}$

The Supreme Court soon made the plight of would-be antitrust plaintiffs even more difficult in Business Electronics Corp. v. Sharp Electronics Corp. ${ }^{79}$ Business Electronics and retailer Gilbert Hartwell had become Sharp Electronic's exclusive dealers for its electronic calculators in the greater Houston area. ${ }^{80}$ Hartwell complained to Sharp on several occasions about Business Electronics's prices, which were generally lower than Hartwell's. ${ }^{81}$ In June 1973, Hartwell threatened to terminate his dealership unless Sharp stopped dealing with Business Electronics within thirty days. ${ }^{82}$ In July 1973, Sharp terminated Business Electronics's dealership. ${ }^{83}$ Sharp had published a list of suggested resale prices, but its contracts with Business Electronics and Hartwell did not require the dealers to observe them or any other specified price. ${ }^{84}$ The Court held that Sharp's arrangements, absent an explicit agreement to maintain a specific price, did not constitute an RPM practice that would be subject to per se treatment. ${ }^{85}$

Subsequent cases construed the rule of Business Electronics broadly by requiring evidence of a specific price agreement before finding an illegal RPM. ${ }^{86}$ As a result, plaintiffs now face a very difficult task in convincing a court that a defendant's efforts to maintain prices went beyond that allowed by the Colgate doctrine. ${ }^{87}$

${ }^{78}$ See supra notes 26-31 and accompanying text (noting the Court's acceptance of the cartel paradigm in deciding upon a per se illegal rule for RPM).

${ }^{79} 485$ U.S. 717 (1988).

${ }^{80}$ See id. at 721.

81 See id.

${ }^{82}$ See id.

${ }^{83}$ See id.

st See id.

${ }^{85}$ See id. at $735-36$ ( $[$ [E]conomic analysis supports the view ... that a vertical restraint is not illegal per se unless it includes some agreement on price or price levels."). Thus, Sharp's practice was subject to the rule of reason analysis articulated in Sylvania. See supra notes 64-68 and accompanying text (discussing the reasoning and holding of Sylvania).

${ }^{86}$ See, e.g., Bi-Rite Oil Co. v. Indiana Farm Bureau Coop. Ass'n, 908 F.2d 200, 203 (7th Cir. 1990) (holding that evidence of a specific agreement on prices is needed to find per se illegality); Jeanery, Inc. v. James Jeans, Inc., 849 F.2d 1148, 1154 (9th Cir. 1988) (holding that proof of an agreement between a distributor and a manufacturer must include more than a showing that the distributor conformed to the suggested price); Ben Elfman \& Son, Inc. v. Criterion Mills, Inc., 774 F. Supp. 683, 686 (D. Mass. 1991) (holding that to withstand a motion to dismiss a plaintiff must show there was a manufacturer-dealer agreement as to price level).

${ }^{87}$ Some commentators have gone so far as to characterize the Business Electronics 
Further, the plight of potential plaintiffs has been compounded by the fact that in recent years application of the rule of reason analysis has resulted in summary judgment for defendants in a significant percentage of private suits. ${ }^{88}$ In the late 1980 s and early 1990s, while the Supreme Court struggled to develop a coherent treatment of RPM, Congress continued its tradition of vacillation toward $\mathrm{RPM}^{89}$ On May 9, 1991, the Senate, in reaction to Monsanto ${ }^{90}$ and Business Electronics, ${ }^{91}$ passed the Consumer Protection Against Price-Fixing Act. ${ }^{92}$ Senator Howard Metzenbaum, one of the Act's main proponents, stated that "[r]ecent Supreme Court decisions have severely eroded the enforceability of the ban against price fixing. ${ }^{93}$ The Act aimed to lighten the evidentiary load on plaintiffs alleging the existence of RPM programs and to enable more RPM cases to reach the jury. ${ }^{94}$ The

decision as practically overruling the per se rule against RPM. See, e.g., Burns, supra note 36, at 28 ("Put simply, following the rationale of Business Electronics, there are no purely vertical restraints that are per se illegal."); Rudolph J. Peritz, A Genealogy of Vertical Restraints Doctrine, 40 HASTINGS L.J. 511, 551 (1989) (arguing that after Business Electronics, "[a]lthough price restraints still fall under the per se rule, the Court has shrunk the category of price restraints to the point of collapse"). In the view of practicing antitrust lawyers, "only the most poorly advised manufacturer" will run afoul of the holding in Business Electronics. Maxwell M. Blecher, The Impact of GTE Sylvania on Antitrust Jurisprudence, 60 ANTITRUST L.J. 17, 20 (1991) (noting that the "standard of proof for conspiracy is so great that in the absence of an express agreement to resell at a given price, the offering manufacturer can largely evade legal sanction"); see also Thomas A. Piraino, Jr., Reconciling the Per Se and Rule of Reason Approaches to Antitrust Analysis, 64 S. CAL. L. REv. 685, 686 (1991) (noting that in the past ten years "the rule of reason has achieved a dominant role in antitrust analysis").

${ }^{83}$ See John J. Flynn, Which Past Is Prolog? The Future of Private Antitrust Enforcement, 35 ANTITRUST BULL. 879, 920 (1990) (noting that in recent years summary judgment motions have been granted in whole or in part in over $50 \%$ percent of private antitrust cases); see also Baxter, supra note 42, at 949 (arguing that application of the rule of reason analysis has become tantamount to per se legality).

${ }^{89}$ From 1919 to 1936, RPM was subject to only the judicially created per se rule of Dr. Miles Medical, as qualified by Colgate, with no explicit congressional treatment. From 1937 to 1975 , RPM was partially exempted from antitrust scrutiny by the MillerTydings Enabling Amendment. Since 1975, no definitive congressional statement regarding RPM has been incorporated into the Sherman Antitrust Act.

${ }^{90} 465$ U.S. 752.

91485 U.S. 717.

${ }^{92}$ S. 429, 102d Cong., 1st Sess. (1991). On October 10, 1991, the House passed its version of an anti-RPM bill, the Price Fixing Prevention Act of 1991, H.R. 1470, 102d Cong., 1st Sess. Other anti-RPM bills had been proposed in 1987 and 1990. See Thomas A. Piraino, Jr., A Reformed Antitrust Approach to Distributor Terminations, 68 NOTRE DAME L. REv. 271, 271 n.4 (1992) (reviewing congressional treatment of RPM).

${ }^{93} 137$ CoNG. REC. S2006 (daily ed. Feb. 20, 1991) (statement of Sen. Metzenbaum).

${ }^{94}$ See $\mathrm{S} .429 \S 8(\mathrm{a})(1)(\mathrm{B})(\mathrm{ii})$ (requiring a judge to send the case to the jury if he 
House of Representatives, however, soundly defeated the bill, revealing the deep division in Congress concerning the proper treatment of RPM. ${ }^{95}$ Opponents of the bill expressed concern that the bill, if enacted, would subject "thousands of small businesses to unsubstantiated lawsuits. "96 Thus far, no subsequent anti-RPM bills have been presented for consideration in Congress.

\section{G. Problems with the Current State of the Law}

As a result of these judicial and legislative developments, the current state of the law regarding RPM is unsatisfactory from many vantage points. The per se illegality of RPM is a strong candidate for the title of "most criticized rule of American law." 97 By virtue of the per se rule, courts are precluded from inquiring into the possible procompetitive effects of the restraints involved and must instead focus on the presence or absence of an agreement. ${ }^{98}$ At the same time, the Monsanto ${ }^{99}$ and Business Electronics ${ }^{100}$ line of cases, which require direct evidence of a specific agreement as to price, emphasizes seemingly arbitrary distinctions in consideration of alleged RPM arrangements. As a result, courts apply the rule of reason test to many arrangements that appear to be price restraints with collusive and horizontal elements. ${ }^{101}$ As Justice Stevens stated in his dissent in Business Electronics, although the majority assumed, "without analysis," that the case did not involve an agreement to fix prices, "the restraint that results when one or more

determines that the "request, demand, or threat" of a price cutter's competitor is the "major" cause of a manufacturer's decision to terminate the price cutter).

${ }_{95}^{5}$ See 63 Antitrust \& Trade Reg. Rep. (BNA) No. 1572, at 3 (July 2, 1992).

${ }^{96} \mathrm{Id}$.

${ }^{97}$ Most of the criticism has made the point that often the economic effects of vertical price restraints are identical to those created by nonprice vertical restraints, which are judged under the rule of reason standard. The commentary criticizing the per se illegality of RPM is legion, but the following represent some of the more influential and widely-quoted works criticizing the rule of Dr. Miles Medical: ROBERT H. BORK, THE ANTITRUST PARADOX: A POLICY AT WAR WITH ITSELF (1978); RICHARD A. POSNER, ANTITRUST LAW: AN ECONOMIC PERSPECTIVE (1976); Bork, supra note 32; Lester G. Telser, Why Should Manufacturers Want Fair Trade?, 3 J.L. \& EcoN. 86 (1960).

${ }^{98}$ See supra notes 20-22 and accompanying text (discussing the per se approach and its lack of a detailed inquiry into the possible positive effects of the restraint or conduct at issue).

99465 U.S. 752.

100485 U.S. 717.

${ }^{101}$ See supra notes 71-88 and accompanying text (discussing the impact of the Monsanto and Business Electronics decisions). 
dealers threaten to boycott a manufacturer unless it terminates its relationship with a price-cutting retailer is more properly viewed as a 'horizontal restraint' [than as an instance of RPM or a nonprice vertical restraint]." 102

Given the wide dissatisfaction with the current treatment of RPM and other vertical price restraints as supported by the cartel paradigm, change in the law seems likely. The remainder of this Comment attempts to predict the probable nature of the change.

\section{Two PERSPECTIVES ON ANTITRUST AND ECONOMICS: THE ChICAgo SCHOOL AND TRANSACTION COST ECONOMICS}

The cartel paradigm assumes that the only plausible explanations for RPM are anticompetitive ones. Procompetitive explanations for RPM do exist, however, despite the fact that the judicial discussions of RPM have rarely acknowledged their viability. ${ }^{103}$ These justifications can be drawn from either of two schools of economics and antitrust: the Chicago School and transaction cost economics. To provide the theoretical context essential to understanding how these two perspectives attempt to justify RPM, the following discussion examines the essential aspects of each.

\section{A. The Chicago School}

1. Tools of the Trade

The Chicago School ${ }^{104}$ is the economic perspective that has benefitted most from the growing influence of economics in antitrust analysis. ${ }^{105}$ The Chicago School analysis, for the most

102485 U.S. at 736 (Stevens, J., dissenting).

${ }^{103}$ See, e.g., supra part I.B.1 (discussing the Sylvania Court's treatment of RPM).

${ }^{104}$ The following discussion is a simplification of the Chicago approach for the purposes of contrast with transaction cost economics only. For a more complete treatment of where the Chicago School fits in the greater mosaic of economic theories, see generally BARRY Clark, POltTiCal ECONOMY: A CoMparative APPROACH (1991); HARRY LANDRETH \& DAVID C. COLANDER, HISTORY OF ECONOMIC THEORY (2d ed. 1989); RICHARD D. WOLFF \& STEPHEN A. RESNICK, ECONOMICS: MARXIAN Versus NeOCLASSICAL (1987); Eleanor M. Fox \& Lawrence A. Sullivan, Antitrust-Retrospective and Prospective: Where Are We Coming From? Where Are We Going?, 62 N.Y.U. L. REv. 936, 956-59 (1987).

${ }^{105}$ Most observers agree that the Sylvania decision, see supra notes 56-61 and accompanying text, represented a breakthrough in respect for economic analysis in general, and for the Chicago School in particular. See, e.g., Kattan, supra note 2, at 25-26 (discussing the Court's "eager acceptance of economic theory" in Sylvania). 
part, relies on the assumptions of neoclassical price theory and perfect competition. ${ }^{106}$ Neoclassical price theory envisions the various markets for goods as composed of many buyers and sellers, none of whom can affect the prevailing price of any good. ${ }^{107}$ Neoclassical price theory further assumes that all market participants possess full and correct (perfect) information regarding all factors relevant to production and consumption decisions. All market participants are presumed to be rational actors who act upon perfect information to maximize their total utility or satisfaction. The theory also assumes that assets are freely transferrable between alternate uses, resulting in the smooth flow of resources from one market to another to correct imbalances. ${ }^{108}$ In addition, all competing products within a given market are assumed to be perfectly homogenous. ${ }^{109}$ Although economists have failed to identify a single market that is truly perfectly competitive, Chicago School adherents choose to assume away the differences between the model and the real world. ${ }^{110}$

Groundwork for the Sylvania decision, however, was laid beginning in 1965 with a series of appointments of economists to leading advisory and decision-making positions within the Antitrust Division of the DOJ and the FTC. See John E. Kwoka, Jr. \& Lawrence J. White, Introduction to THE ANTITRUST REVOLUTION, supra note 34, at 1, 1-2 (discussing the institutionalization of economists within the antitrust enforcement agencies). The Reagan administration's appointment of William Baxter to the position of Assistant Attorney General for Antitrust at the DOJ continued economics conquest of antitrust and led to the establishment of the Chicago world view as the dominant antitrust perspective throughout the 1980s. See Fox \& Sullivan, supra note 104, at $944-45$ (discussing Baxter's impact on antitrust policy).

${ }^{105}$ For more complete expositions of neoclassical price theory, see generally RALPH T. BYRNS \& GERALD W. STONE, MICROECONOMICS (4th ed. 1989); STEven E. Landsburg, Price Theory and Applications (1989); Paul A. Samuelson \& WILLIAM D. NORDHAUS, ECONOMICS (12th ed. 1985); GEORGE J. STIGLER, THE THEORY OF PRICE (3d ed. 1966).

${ }^{107}$ See SAMUELSON \& NORDHAUS, supra note 106, at 47 ("The economic definition of perfect competition in a market is a sufficient number of firms or degree of rivalry such that no one firm can affect the price of that good.").

${ }^{108}$ See BYRNS \& STONE, supra note 106, at 184 (noting that in a perfectly competitive market, at least in the long run, resources will be able to freely enter or leave markets). Thus, if owners of productive assets observe that manufacturers in a particular market are enjoying high levels of profits, they will enter the market to compete for the perceived excess profits. Eventually, this additional competition will dissipate the excess profits. See id. (stating that in a perfectly competitive market "[n] ew firms can easily enter . . . [an] industry if doing so appears profitable"). This state of affairs depends on the absence of barriers to entry. See infra note 142 and accompanying text (discussing the prevalence of barriers to entry).

${ }^{109}$ See BYRNS \& STONE, supra note 106, at 170 (defining a perfectly competitive market as one in which, inter alia, firms produce a homogenous good).

110 "Market failures, including informational failures, can occur for a variety of 
The Chicago School contends that economic efficiency should be the only goal of antitrust policy and that the pursuit of noneconomic goals through antitrust enforcement leads to undesirable results. ${ }^{111}$ Efficient conduct is defined as conduct that increases output or consumer welfare. ${ }^{112}$ Chicago scholars argue that the unfettered functioning of the market, not the antitrust laws, best serves to discipline undesirable market restrictions. ${ }^{113}$ Thus, according to the Chicago School, antitrust enforcement should be limited to the regulation of collusive attempts to obtain and abuse monopoly power or to restrict output. ${ }^{114}$

reasons, but textbook competition is assumed to be the normal state of affairs while market failure is seen as a condition to be proved in particular markets." Kattan, supra note 2, at 22. Others beg to differ, however, contending that economists relying on models of perfect competition have no "professional knowledge on which to base recommendations [in the antitrust area] that should carry weight with a skeptical legislator." George J. Stigler, The Economists and the Problem of Monopoly, 72 AM. ECON. REV. 1, 6 (1982).

111 See BORK, supra note 97, at 117 ("To abandon economic theory is to abandon the possibility of a rational antitrust law."); see also Wesley J. Liebeler, What Are the Alternatives to Chicago?, 1987 DUKE L.J. 879, 880 (arguing that failure to employ an economic efficiency approach will lead to an unworkable set of antitrust laws).

112 But see Tyler A. Baker, Interconnected Problems of Doctrine and Economics in the Section One Labyrinth: Is Sylvania A Way Out?, 67 VA. L. REv. 1457, 1489 (1981) (noting that market-wide cartels, which are condemned even by Chicago School adherents, produce "higher prices and reduced output"). In an intuitive sense, consumer welfare is "the amount over and above the price actually paid that a man would be willing to pay for a given amount of a commodity rather than go without it." STICLER, supra note 106, at 78. It follows that, in the aggregate, the total consumer surplus produced by a commodity is the difference between the total amount of value purchasers would have paid for a good and the total amount actually paid by the purchasers.

"13 See, e.g., Frank H. Easterbrook, The Limits of Antitrust, 63 TEx. L. REV. 1, 24 (1984) ("One need not pretend that markets work perfectly to see that they are better than judges at penalizing inappropriate conduct."); Frank H. Easterbrook, Workable Antitrust Policy, 84 MiCH. L. REV. 1696, 1700 (1986) ("No antitrust policy should be based on a belief that courts and other institutions of government can identify the "best' structure of a market.").

I14 See, e.g., Ernest Gellhorn, The Practical Uses of Economic Analysis: Hope vs. Reality, 56 ANTITRUST L.J. 933, 940 (1987) (arguing for per se legality treatment of RPM and other vertical restraints); Richard A. Posner, The Chicago School of Antitrust Analysis, 127 U. PA. L. REV. 925, 928 (1979) (arguing for diminishing the scope of antitrust scrutiny). Chicago scholars are skeptical that a single manufacturer will unilaterally impose an inefficient distribution system, because to do so would reduce the manufacturer's profits. See id. ("F F]irms cannot in general obtain or enhance monopoly power by unilateral action-unless, of course, they are irrationally willing to trade profits for position." (footnote omitted)). Because, however, collusive behavior and conscious attempts to monopolize are attempts to override the workings of the market they present problems that the market itself may not be able to regulate and punish. See Jacobs, supra note 4, at 346 (stating that because barriers to 


\section{Perceived Effects of the Chicago School}

As the Chicago School has gained prominence, antitrust policy and enforcement, not coincidentally, have become increasingly minimalist. ${ }^{115}$ This minimalism has surfaced in the courts, ${ }^{116}$ in the government agencies assigned the task of enforcing the Sherman Act and other antitrust legislation, ${ }^{117}$ and in the behavior of private plaintiffs. ${ }^{118}$

One of the Supreme Court's most significant recent contributions to this narrowing of inquiry in antitrust came in Matsushita Electric Industrial Co. $v$. Zenith Radio Corp. ${ }^{119}$ In disposing of the

perfect competition, such as unlawful acquisition and abuse of monopoly power, are "produced by market participants, not by the workings of the market itself, [they] are analytically distinguishable from structural 'market failures'").

${ }^{115}$ See, e.g., Kwoka \& White, supra note 105 , at 5 (discussing how the rise of the Chicago School has "narrowed the bounds of what may be thought of as rational, acceptable antitrust policy").

${ }^{116}$ In discussing the Supreme Court's recent antitrust decisions, Michael S. Jacobs notes that over the past fifteen years, "almost without exception, the Court consistently contracted the scope of judicial involvement in antitrust enforcement, often relying on economic theory to resolve disputed issues at the summary judgment stage." Jacobs, supra note 4, at 360 (citation omitted). In the area of horizontal restraints, the courts' increasingly defendant-friendly tendencies in applying the rule of reason test have discouraged the Government from instituting suits. See, e.g., Mary L. Azcuenaga, Market Power as a Screen in Evaluating Horizontal Restraints, 60 ANTITRUST L.J. 935, 936 (1992) ("I can say with some certainty, however, that if [certain aspects of the rule of reason test] always were required, many or, possibly, most health care cases would not be brought simply because the litigation cost would [well] outweigh the benefits of the case ....").

${ }^{117}$ See Earl E. Pollock, The "New Antitrust": Its Implications for the Practitioner, 54 ANTITRUST L.J. 51 (1985) (noting the declining number of antitrust cases brought by the Government). The DOJ has intervened as amicus curiae to argue for the relaxation of judicial standards toward vertical price restraints. In addition, the DOJ's Vertical Restraints Guidelines, issued in 1985, demonstrated considerable tolerance for vertical restraints. See supra note 70 (discussing the DOJ's guidelines).

${ }^{118}$ See Blecher, supra note 87, at 17 n.2 ("[T]he General Accounting Office reported that the number of private antitrust cases filed each year fell by more than 50\% during the 1980's, from 1457 in 1980 to 638 in 1989. Thus far, the 1990's have continued that trend, with only 521 suits filed in 1990."(footnote omitted)). Potential private plaintiffs have also been discouraged by rules such as the one set forth in Illinois Brick Co. v. Illinois, 431 U.S. 720 (1977), which limits antitrust recovery to direct purchasers of a defendant's products.

119475 U.S. 574 (1986). In Matsushita, the plaintiffs, American television distributors, charged that the defendants, Japanese television distributors and their American subsidiaries, engaged in a collusive predatory pricing scheme. A predatory pricing scheme involves a conspiracy to charge artificially low prices in order to drive a competitor out of business. The conspirators intend to recoup any losses sustained in the price reductions by charging higher prices after the competitor leaves the scene. After twelve years of discovery and lower court proceedings, the case arrived 
plaintiffs' claims of a predatory pricing scheme, the Court stressed the implausibility of the allegations when viewed in the light of conventional, neoclassical economic theory. ${ }^{120}$ In Matsushita, the Court found that the existence of a collusive predatory pricing scheme was implausible given that members of the scheme would have to allocate losses from the price cutting, thus creating incentives to cheat. ${ }^{121}$ Given that prevailing economic theory was skeptical of the potential for a viable predatory pricing scheme, the Court required the plaintiffs to present "more persuasive evidence to support their claim than would otherwise be necessary. ${ }^{122}$

Thus, the Matsushita Court employed economic theory to alter the prevailing standard for summary judgment. ${ }^{123}$ Until Ko$d a k,{ }^{124}$ it appeared that the Matsushita Court imposed a greater burden on plaintiffs who sought to avoid summary judgment in antitrust cases than in other areas of the law. ${ }^{125}$ Matsushita was viewed as yet another sign of the Chicago School's dominance. ${ }^{126}$

before the Supreme Court. See id. at 577-79.

${ }^{120}$ The Supreme Court held that in the summary judgment context, "courts should not permit fact-finders to infer [anticompetitive intent and/or effect] when such inferences are implausible." Id. at 593.

${ }^{121}$ See id. at 589 ("[T]he success of such schemes is inherently uncertain: the short-run loss is definite, but the long-run gain depends on successfully neutralizing the competition.").

${ }^{122}$ Id. at 587; see also id. at 589 (citing BORK, supra note 97, in setting out its conception of the applicable economic theory).

${ }^{123}$ See Susan L. Watchman, Note, Summary Judgment in Antitrust Cases-Is the Standard Changing? Matsushita Electric Industrial Co. v. Zenith Radio Corp., 475 U.S. 574 (1986), 20 ARIz. ST. L.J. 591, 593 (1988) ("The Court defined the basic legal elements of predatory pricing, including the threshold requirement that a plaintiff who relies on circumstantial evidence of predatory pricing must demonstrate that his claim is economically plausible.").

124112 S. Ct. 2072 (1992). For a full discussion of Kodak, see infra part IV.A.

${ }^{125}$ See Stephen Calkins, Summary Judgment, Motions to Dismiss, and Other Examples of Equilibrating Tendencies in the Antitrust System, 74 GEO. L.J. 1065, 1126 (1986) ("The [Matsushita] Court's language 'suggests that a judge hearing a defendant's motion for summary judgment in an antitrust case should go beyond the traditional summary judgment inquiry and decide for himself whether the weight of the evidence favors the plaintiff.' (quoting Matsushita, 475 U.S. at 600 (White, J., dissenting))); Susan S. DeSanti \& William E. Kovacic, Matsushita: Its Construction and Application by the Lower Courts, 59 ANTITRUST L.J. 609, 610 (1991) ("Many commentators initially predicted that Matsushita would enable defendants to obtain summary judgment far more easily than before."); Watchman, supra note 123, at $592-93$ (noting that the summary judgment standard employed by the Matsushita Court conflicts with traditional summary judgment requirements). For a discussion of the Kodak Court's treatment of Matsushita, see infra notes $192-95$ and accompanying text.

${ }^{126}$ See, e.g., Roger D. Blair et al., An Economic Analysis of Matsushita, 36 ANTITRUST BuLL. 355, 380 (1991) (noting that the Matsushita decision "represents a continuation 


\section{B. Transaction Cost Economics}

Despite the considerable amount of academic work generated in the area, ${ }^{127}$ transaction cost economics, in contrast to Chicago School economics, has received little recognition from the Supreme Court. ${ }^{128}$ In this context it is important to note that, while transaction cost economics embodies a decidedly non-Chicago approach to economics, the two schools have some common ground. ${ }^{129}$

Transaction cost economists are not as easily categorized or as doctrinally homogenous as Chicago School adherents; in general, however, transaction cost economics focuses on the ways in which the operation of markets differs from that predicted by the Chicago School. ${ }^{130}$ The following discussion highlights analytical tools

of the trend to incorporate more sophisticated economic reasoning into judicial decisions" and finding "Zenith's allegations of predatory pricing . . . not compelling since it appeared economically implausible ${ }^{n}$ ).

${ }^{127}$ Perhaps the transaction cost approach has suffered from the lack of distinguished jurists who espouse its principles. The Chicago School has certainly benefitted from the support of Bork, Easterbrook, Posner, and others. The approach also seems to lack the appetite for conquest exhibited by the Chicago School, see infra note 169 , although some transaction cost theorists have displayed glimmers of the requisite arrogance. See, e.g., Klein \& Murphy, supra note 27, at 280, 296 ("Our framework unifies the efficiency theory of price and nonprice vertical restraints. . . . Our theory ... corresponds much more closely with reality [than other theories]."). A more fundamental reason for the lack of influence exerted by transaction cost economics on antitrust jurisprudence may be the anecdotal and heavily contextual nature of transaction cost arguments, which contrasts with the neat, theoretically-grounded Chicago School depictions of market behavior.

${ }^{128}$ In Jefferson Parish Hosp. Dist. No. 2 v. Hyde, 466 U.S. 2 (1984), the Court specifically rejected the argument that informational market imperfections could confer significant market power on a hospital with a $30 \%$ market share. The Court, while recognizing the presence of the informational deficiencies, held that the market power conferred by the deficiencies was "abstract," and was not the "kind of market power" with which the Court was concerned. Id. at 27.

${ }^{129}$ Although a complete treatment of the similarities of the two paradigms is beyond the scope of this Comment, certain points are worth noting. Transaction cost economics is not, for example, a theory that purports to present a sociopolitical critique of the neoclassical economic school, as is Marxism. For a discussion of Marxism as compared to neoclassical theory, see generally WOLFF \& RESNICK, supra note 104. Transaction cost economics, like the Chicago School, is mainly microeconomic in focus in that it examines the actions of individual actors and markets. Both theories build upon the assumption that individuals seek to maximize their satisfaction or utility from the resources available. A perusal of the literature generated by both camps reveals the use of some standard analytical tools, such as the familiar demand, supply, and marginal cost curves. Thus, theoretically speaking, the two paradigms could be said to be estranged siblings. " [T] he degree to which information is believed to be imperfect accounts for much of what separates 'post-Chicago' antitrust from Chicago-School antitrust." Lande, supra note 10, at 193.

${ }^{130}$ See Lande, supra note 10, at 193 ("The Chicago School believes that the 
commonly used by transaction cost economics. These analytical tools are important to an understanding of the Kodak Court's reasoning and of how transaction cost economics supports the use of RPM as a defensible practice.

\section{Tools of the Trade}

Transaction cost economics places particular emphasis on the following concepts to support its world view: the prevalence of transaction costs and their effects on market participants, the theory of monopolistic competition, and game theory. The following discussion illustrates these concepts.

\section{a. The Nature and Effects of Transaction Costs}

Transaction cost scholars view transaction costs, defined as the costs incurred in transferring a good or service "across a technologically separable interface, ${ }^{n 131}$ as critical determinants of the way businesses and industries structure themselves. ${ }^{132}$ Such concepts do not take center stage in the Chicago School model. ${ }^{133}$

Transaction costs can be conceptualized as arising from four main sources: bounded rationality, uncertainty, opportunism, and asset specificity. ${ }^{134}$ Bounded rationality refers to the computational limits and information gaps people face in obtaining and handling information. ${ }^{135} \mathrm{~A}$ manager may face bounded rationality

suboptimal effects from imperfect information are relatively rare, while the postChicago school believes that they are often common enough to affect competition in a market.").

131 OLIVER E. WILliamson, THE ECONOMIC INSTITUTIONS OF CAPITALISM 1 (1985); see id. at 19 ("Transaction costs are the economic equivalent of friction in physical systems.").

${ }^{132}$ See id. at 95-130 (arguing specifically that the presence of transaction costs explains the choices companies make between vertical integration and vertical restraints).

133 The differences in the terminologies and usages illustrate the fundamental clash of the two perspectives. The transactional economist sees informational problems and the like as essential components of the market's normal operation. The Chicago School views problems of uncertainty and limited information as aberrational and terms them "market failures." For a discussion of the neoclassical theory's treatment of market failures, see generally STICLER, supra note 106.

194 See WILliamson, supra note 131, at 43-68 (describing behavioral assumptions of transaction cost economics, which include rationality and opportunism, and principal dimensions with respect to which transactions differ, such as asset specificity and uncertainty).

${ }^{135}$ See id. at 45-46 (noting that bounded rationality is a "semistrong form of rationality in which economic actors are assumed to be 'intendedly rational, but only 
when she is confronted with so much data or so many details pertaining to her responsibilities that she cannot manage effectively. A company may face bounded rationality when it cannot obtain reliable information on whether a particular distributor is conforming to its contractual obligations.

Uncertainty may exist when a contracting party cannot draft explicit contractual provisions to cover all possible contingencies that may arise during the executory period of a contract. ${ }^{136}$ Uncertainty naturally results in underspecific contract drafting, which in turn opens the door for another source of transaction costs: opportunism. Companies practice opportunism when they misrepresent reality to further their interests. ${ }^{137}$ A final source of transaction costs, asset specificity, refers to the investments that companies make to do business with other companies and that have value for only one or limited purposes. ${ }^{138}$ The pervasive presence of asset specificity makes changes in operations and/or expansions into new markets much more difficult for market participants. ${ }^{139}$

limitedly so"). The concept of bounded rationality takes into account the fact that the assumption of perfect information in all situations is unrealistic. Thus, in the real world, a market participant will almost never possess all information useful in making a decision, but instead is forced to guess or predict current and future conditions and events. Even if a market participant has access to every pertinent piece of information, it is doubtful that the participant can utilize all of the information meaningfully in production or consumption decisions.

${ }^{136}$ See id. at 56-60. Contingencies, such as changes in the costs of key production inputs, shifts in consumer demand, imposition of government regulations, competitive responses of rivals, and presence of new entrants to the market, can drastically affect the economic impact of a contract. Uncertainty is another systemic source of informational deficiency that is assumed away by the model of perfect competition.

${ }^{137}$ Opportunism is "self-interest seeking with guile." Id. at 47. Although the Chicago School's perfectly competitive model assumes that all actors will act rationally in their best interests and may therefore attempt to take advantage of others in their dealings when the penalties for doing so are not prohibitive, the presence of perfect information for the most part nullifies the effect of such opportunistic behavior. In the absence of perfect information, there is much less of a self-operative systemic check on opportunistic behavior.

${ }^{138}$ See id. at 30 . Thus, with respect to alternate uses, specific assets may have little salvage value.

${ }^{139}$ Obviously a firm owning specific assets cannot convert them without cost to new uses, but must make additional expenditures to change its operations. Asset specificity erodes the empirical relevance of the Chicago School assumptions of the perfect transferability of productive assets and the lack of barriers to market entry. 


\section{b. Monopolistic Competition}

As part of their focus on the empirical limits of the fundamental assumptions of perfect competition, transaction cost scholars often rely on models of monopolistic competition in constructing their arguments. ${ }^{140}$ The theory of monopolistic competition challenges many key neoclassical assumptions, ${ }^{141}$ including the lack of barriers to entry ${ }^{142}$ and perfect product homogeneity. ${ }^{143}$

A key feature of the theory of monopolistic competition is the assumption that firms are consciously interdependent. In the perfectly competitive world envisioned by the Chicago School, market participants are too small to affect price and output levels appreciably. By contrast, theories of monopolistic competition attempt to demonstrate "that a firm's actions usually do have indirect effects and that firms will recognize this fact and be aware of their consequent interdependence with other firms." ${ }^{144}$ The aspect of conscious interdependence also introduces the risk

${ }^{140}$ The following discussion is intended only as a brief summary of some of the more important aspects of the theory of monopolistic competition. For the theory as originally presented, see generally EDWARD $\mathrm{H}$. CHAMBERLIN, THE THEORY OF MONOPOLISTIC COMPETITION (6th ed. 1950). As the following discussion indicates, transaction cost economics and theories of monopolistic competition go hand in hand, because transaction costs are the major cause of many structural and behavioral phenomena dealt with by models of monopolistic competition.

${ }^{141}$ Most importantly, monopolistic competition models assume that the normal state of affairs is one somewhere between monopoly (a market supplied by one producer) and perfect competition. According to Chamberlin, the normal operation of markets is characterized not by perfect competition, but by "the attempt of every business man to build up his own monopoly, [extending] it wherever possible." Id. at 213-14.

${ }^{142}$ These barriers to entry are generated in part by asset specificity, to the extent that certain machinery cannot be transferred to alternate uses. In addition, problems of bounded rationality usually ensure that market entrants will require time and experience to compete optimally. The result will be that market entrants normally cannot instantly exert pressure on incumbent firms, as envisioned by theories of perfect competition.

${ }^{143}$ If a producer can differentiate her product from others through the use of innovation, advertising and promotional efforts, or other pre-and post-sale services, she will, in effect, create a range of prices in which she has a monopoly for that product. By virtue of her differentiation efforts, consumers will perceive her product as unique from all others, if only to a slight extent. If, however, she begins to charge prices above that monopoly range, consumers will become indifferent between her product and other products. See Steven C. Salop, Monopolistic Competition with Outside Goods, 10 BELL J. ECON. 141, 145 (1979) (arguing that when a competitor begins charging lower prices than a monopolist, there comes a point at which consumers will switch to the competitor, even if they prefer the monopolist's product).

144 LANDRETH \& COLANDER, supra note 104, at 340. 
preferences of the market participants as an important variable in predicting market performance, because market participants may compose their strategies with the various risks presented by competitors' responses in mind. ${ }^{145}$

The theory of monopolistic competition does not lend itself well to theoretical generalizations. Although the theory of monopolistic competition is "rich in contextual argument," it is difficult to use in a "mathematical or general equilibrium framework."146 This limitation militates against incorporation of the theory of monopolistic competition into mainstream economic thinking. ${ }^{147}$ Because the theory of monopolistic competition is more hospitable to arguments dealing with so-called market imperfections than is the theory of perfect competition, ${ }^{148}$ models of monopolistic competition provide fertile ground for transaction cost arguments.

\section{c. Game Theory}

Transaction cost economists have used game theory in constructing their arguments as a consequence of their recognition of the role opportunism plays in the generation of transaction costs. ${ }^{149}$ Game theory is defined broadly as "the study of strategic interactions among interdependent decision makers." 150 Game theorists attempt to analyze the "costs and benefits of all possible strategies by one [market] participant [when] paired with all possible strategies adopted by an opponent."151 Game theory highlights the fact that

${ }^{145}$ See, e.g., Patrick Rey \& Jean Tirole, The Logic of Vertical Restraints, 76 AM. ECON. REV. 921, 922-38 (1986) (discussing the impact of retailer risk preferences on the desirability of various vertical restraints); see also infra part II.B.1.c (discussing game theory).

${ }^{146}$ LANDRETH \& COLANDER, supra note 104, at 344. The dominant trend in 20 thcentury microeconomics has been one of increased formalization through increasingly sophisticated mathematical models, leading to theories "almost devoid of contextual argument and analysis." Id.

${ }_{147}$ See id. (noting that "the mainstream microeconomics taught and researched at graduate schools in the United States is now highly mathematical").

${ }^{148}$ See supra note 110 and accompanying text (discussing the dismissive attitude taken in theory and practice by Chicago School adherents toward such imperfections).

${ }^{149}$ See supra note 137 and accompanying text (discussing the nature and effects of opportunism).

${ }^{150}$ BYRNS \& STONE, supra note 106, at 233.

${ }^{151} I d$. For a somewhat whimsical treatment of game theory, see generally JoHN MaDONALD, STRATEGY IN POKER, BUSINESS AND WAR II (1950). For a more rigorous explanation of game theory, see generally J.D. WILLIAMS, THE COMPLEAT STRATEGYST (1954). 
market participants do not always exhibit completely rational, utilitymaximizing behavior, as predicted by neoclassical economists. ${ }^{152}$

\section{The Perceived Effects of a Transaction Cost Approach}

Transaction cost arguments do not fit as comfortably into overarching theories as some of the Chicago School assertions because of the variable and nonquantifiable nature of transaction costs. Clearly, the prevailing level of transaction costs in a given market can change over time due to a variety of factors. To provide but one example, the "learning curve" firms traverse as they acquire operational experience and become more efficient is well-documented in the managerial economics literature. ${ }^{153}$ Firms traveling learning curves can reduce their bounded rationality problems, but do so in varying degrees and at rates that are sometimes difficult to forecast.

Furthermore, because transaction cost scholarship often incorporates game theory, transaction cost work tends to be heavily anecdotal. "The many possible tactics that [market participants] might follow depend on specific circumstances in particular markets. ${ }^{\text {154 }}$ Finally, the use of monopolistic competition theory adds further anecdotal and contextual flavor to the transaction cost approach. ${ }^{155}$

Some commentators feel that, because of the "messy" nature of transaction cost economics, broad application of theories with transaction cost emphasis would quickly unmake antitrust jurisprudence. ${ }^{156}$ These dire predictions aside, some observers express

152 For example, a firm faced with a choice between strategy $A$, with high risk and a high expected value, and strategy $B$, with a lower risk and a lower expected value, may choose strategy $B$, even though on average, following strategy $A$ would be more profitable. This result may be due to the fact that, rather than being risk neutral, the people controlling the firm are risk averse. For a discussion of risk aversion in analyzing the purchasing behavior of consumers, see infra notes 218-20 and accompanying text (noting risk aversion as a potential barrier to market entry). In addition, game theory is very useful in the analysis of the value of RPM for contract enforcement. See infra note 238 and accompanying text (discussing contract enforcement in terms of game theory).

${ }^{153}$ See, e.g., Michael E. Porter, Slrategic Interaction Among Firms, in MANAGERIAL ECONOMICS AND OPERATIONS RESEARCH: TECHNIQUES, APPLICATIONS, CASES 143, 144 49 (Edwin Mansfield ed., 5th ed. 1987) (discussing how experience, conceptualized as the learning curve, usually leads to cost reductions).

154 BYRNS \& STONE, supra note 106, at 235.

155 See supra note 146 and accompanying text (discussing the contextual nature of the theory of monopolistic competition).

${ }^{156}$ See Jacobs, supra note 4, at 337 (arguing that Kodak" threatens to confuse and 
optimism about the positive effect transaction cost theories might have on antitrust law, predicting that such theories would lead to greater reliance on factual inquiries and economic reality and less reliance on abstract economic theory. ${ }^{157}$

\section{The Chicago School's PRevious AtTempt to JUSTIFY RPM: THE FREE-RIDER HYPOTHESIS}

Despite its best efforts, the Chicago School has not convinced the courts of the merits of RPM. If the transaction cost approach is to succeed in justifying RPM and to gain judicial acceptance, it must avoid the pitfalls encountered by the Chicago School. Therefore, this Part of the Comment closely examines why Chicago School economists generally support RPM, how they attempted to justify RPM, and why the courts have not accepted this justification.

\section{A. The Chicago School's Support for RPM}

The Chicago School is not skeptical of vertical restraints in general, and RPM in particular. ${ }^{158}$ Chicago School adherents have criticized the cartel enforcement paradigm that forms the basis of the current per se illegality rule of RPM employed by the courts. ${ }^{159}$ A major thrust of the Chicago School's criticism has been that, in many cases, the markets at issue in RPM cases have characteristics that make the existence of a cartel very unlikely. ${ }^{160}$

complicate"); Kattan, supra note 2, at 23 (noting that after Kodak "it may be difficult to erect rules of law on the basis of theory"); Charles F. Rule, Back to the Dark Ages of Antitrust, WALL ST. J., June 17, 1992, at A17 (claiming that the "Supreme Court's decision in the Kodak case shakes [the] faith").

${ }^{157}$ See, e.g., Spivack \& Ellis, supra note 3, at 203 (noting that "Kodak stands for the principle that antitrust cases should not be resolved based solely on economic theory when that theory is inconsistent with the facts"). Although broad use of transaction cost economics undoubtedly would have the potential to affect antitrust policy significantly, see supra notes 2-10 and accompanying text, this Comment confines the discussion of possible effects of the transaction costs theory to the issue of RPM. See infra part IV.

${ }^{158}$ See supra note 114 and accompanying text (pointing out several Chicago School theorists' acceptance of RPM as an efficient market mechanism); see also Richard A. Posner, The Next Step in the Antitrust Treatment of Restricted Distribution: Per Se Legality, 48 U. CHI. L. REV. 6, 25 (1981) (arguing that all purely vertical restrictions in which there is no evidence of horizontal concert of action among dealers or distributors should be legal per se). RPM).

${ }^{159}$ See supra note 97 (noting some widely read criticisms of the per se rule against

${ }^{160}$ Such characteristics include few barriers to entry, light market concentration, and, especially in the retail sector, varying cost conditions. A complete exposition of 
First, the Chicago School's criticism points out that if potential market participants face only insignificant barriers to entry, these potential competitors, attracted by the monopoly profits enjoyed by the cartel members, could enter the market quickly. These potential competitors would likely price-cut to take market share away from the cartel members. ${ }^{161}$ As a result, a cartel is much easier to maintain in a market with substantial barriers to entry and is unlikely to be stable in a market without barriers to entry. ${ }^{162}$

Another market characteristic bearing on the potential for cartelization is market concentration. A market made up of many small retailers or of many small manufacturers is unlikely to exhibit the coordinated pricing behavior associated with a cartel. In any cartel, members have incentives to cheat by cutting prices. Policing a cartel agreement to catch and prevent cheating without being detected by enforcement agencies is difficult, particularly when the cartel involves a large number of participants. ${ }^{163}$

Critics of the cartel paradigm have also focused on the cost conditions of the retailing sector, especially in the analysis of alleged retail cartels. If the retailers servicing a particular market have markups that vary widely from wholesale, it is unlikely that they would be able to come to a consensus regarding the maintained price. " $[\mathrm{N}]$ umerous stores with quite different cost and operating characteristics" can often cause "[c]oordination costs . . . to be high $\ldots$ and cartelization unlikely. ${ }^{n 64}$

the criticisms leveled at the cartel enforcement paradigm would be well beyond the scope of this Comment. The following brief discussion is intended for the purposes of illustration only, and does not represent the totality of the academic commentary.

${ }^{161}$ See supra note 108 and accompanying text (discussing the neoclassical assumptions of perfect transferability of productive assets).

162 Barriers to entry may arise from a multitude of factors, including high capital requirements, patent control, or economies of scale. See Sharon Oster, The FTC $v$. Levi Strauss: An Analysis of the Economic Issues, in IMPACT EVALUATIONS OF FEDERAL TRADE COMMISSION VERTICAL RESTRAINTS CASES 47, 57 (Ronald N. Lafferty et al. eds., 1984) ("Entry is very easy [when] there are virtually no economies to scale, no patent or raw material control, and capital requirements are low."); see also infra part $\mathrm{V}$ (discussing how barriers to entries can arise in ways not predicted by neoclassical price theory).

${ }^{163}$ See BYRNS \& STONE, supra note 106, at 231-33 (offering a general discussion of the incentives of cartel members to cheat and the likelihood of their detection). Presumably, the difficulties of maintaining the cartel would increase sharply as the number of conspirators rose, because cartel members would have to worry about the potential bad faith of a greater number of cartel members.

${ }^{164}$ Oster, supra note 162 , at 59-60. 
Because Chicago School adherents view cartelization as so unlikely to occur, they reason that, in the majority of cases, the cartel explanation of RPM was of extremely limited value. Consequently, Chicago School theorists felt that some other dynamic motivated manufacturers to institute RPM. The Chicago School was simply unconvinced that RPM was invariably imposed for anticompetitive reasons or that RPM caused undesirable effects. Therefore, the Chicago School presented an alternative theory that not only explained the occurrence of RPM, but also justified its use: the free-rider hypothesis.

\section{B. The Free-Rider Hypothesis}

The primary Chicago School justification of RPM is the freerider hypothesis, articulated most famously by Lester Telser in $1960 .{ }^{165}$ The paradigmatic free-rider situation assumes that a manufacturer produces a good, and that the total demand for this good is strongly and positively correlated to the amount of point-ofsale service provided by retailers, such as pre-sale information and product demonstration. Provision of these services by retailers, however, costs money. Further, an opportunistic consumer could visit a retailer that provided these point-of-sale services, and then walk down the street to a discounter to buy the same product at a lower price. In this situation, both the consumer and the discounter "free ride" on the effort and expense of the higher-end retailers providing the point-of-sale services. A manufacturer can attempt to remedy this situation by instituting an RPM program. RPM insures that a discounter cannot benefit from the efforts of high-end retailers.

\section{Rejection of the Free-Rider Hypothesis}

Despite the intuitive force of the free-rider argument, considerable opposition to RPM remains. ${ }^{166}$ Two factors explain why the

${ }^{165}$ See Telser, supra note 97 , at 89 . The free-rider hypothesis was also advanced in the Monsanto case to explain the vertical restraints imposed by the Monsanto company. See Warren-Boulton, supra note 76, at 390-98 ("Indeed, Monsanto ... provide[d] almost a textbook example of the free-rider scenario: a complex product, where the provision of complete and accurate presale information is crucial, sold by a discounting broker.").

${ }^{166}$ The letter of New York State Attorney General Robert Abrams, written to the Editor of the New York Times, illustrates the attitude of many enforcement figures toward the free-rider argument. See Robert Abrams, Price Fixing Always Victimizes the 
Chicago School approach, so dominant in other areas of antitrust jurisprudence, ${ }^{167}$ has been so firmly rejected in the area of RPM. ${ }^{168}$ First, some of the rejection of the Chicago School hypothesis reflects the substantial populist underpinnings of the Sherman Act itself. ${ }^{169}$ The statements of Senator Metzenbaum

Consumer, N.Y. TIMEs, Apr. 18, 1991, at A24. In his letter, Abrams responds to a New York Times editorial which referred to the Consumer Protection Against Price-Fixing Bill of 1991 as "legislative overkill." Price Fixing Isn't Always Gouging, N.Y. TimEs, Apr. 1, 1991, at A24. Abrams refers to an FTC enforcement action against Mitsubishi for alleged price-fixing in support of his proposition that the bill is a necessary measure. See Abrams, supra, at A24. Abrams also claims that "[i]f manufacturers want better service, there are dozens of legal ways to require it directly, short of fixing and raising retail prices." Id.

167 This dominance has not been well received by all observers. Some commentators have argued strongly for a greater emphasis on social and political goals in antitrust policy. See, e.g., Jean W. Burns, Vertical Restraints, Efficiency, and the Real World, 62 FORDHAM L. REV. 597, 651 (1993) (concluding that "[ $t$ ] he time has now come to move away from theory and consider the real world and societal needs"); John J. Flynn \& James F. Ponsoldt, Legal Reasoning and the Jurisprudence of Vertical Restraints: The Limitations of Neoclassical Economic Analysis in the Resolution of Antitrust Disputes, 62 N.Y.U. L. REV. 1125, 1138 (1987) (citing "four major historical goals of antitrust [including:] (1) dispersion of economic power, (2) freedom and opportunity to compete on the merits, (3) satisfaction of consumers, and (4) protection of the competition process as market governor ${ }^{n}$ ); Fox \& Sullivan, supra note 104, at 956-57 (noting that "the [antitrust] law [contains] social goals other than or in addition to allocative efficiency"); see also MARK A. LUTZ \& KENNETH LUX, HUMANISTIC ECONOMICS: THE NEW CHALLENGE 170-99 (1988) (cautioning against the encroachment of economic analysis into all areas of thought, especially law, a phenomenon that the authors refer to as "economic imperialism"). Certainly, the statements of Robert Bork would do nothing to assuage the fears of those who share Lutz and Lux's opinion: "There is no body of knowledge other than conventional price theory that can serve as a guide to the effects of business behavior upon consumer welfare." BORK, supra note 97, at 117.

${ }^{169}$ As explored in Part I, courts currently subscribe to the cartel enforcement explanation for RPM.

${ }^{169}$ Most commentators and historians agree that the Sherman Act was enacted in response to the increasing dominance of the trust. Trusts were formed by the pooling of stock by the owners of formerly competitive businesses. After the pooling was achieved, a single group of owners controlled most of the market. Many commentators perceived trusts, and entities like them, as the oppressors of small business owners and consumers. See, e.g., WILlIAM LETwIN, LAW AND ECONOMIC POlicy In America: The Evolution of THE Sherman AntrTrust ACt 70 (1965) ("Trusts, it was said ... drove out competitors by lowering prices [and] victimized consumers by raising prices .... . ); JERROLd G. VAN CISE \& WILLIAM T. LIFLAND, UNDERSTANDING THE ANTITRUST LAwS 15, 16 (8th ed. 1980) (quoting Senator John Sherman, who accused the trusts of making competition impossible by crushing the "humble man [who] starts a business in opposition"); Robert H. Lande, Wealth Transfers as the Original and Primary Concern of Antitmest: The Efficiency Interpretation Challenged, 34 HASTINGS L.J. 67, 74-77 (1982) ("Condemnation of monopoly pricing .. . [is] the only practical method of preventing monopolies from 'unfairly' taking property that, in the view of Congress, belongs to consumers."). 
made in support of the Consumer Protection Against Price-Fixing Bill of 1991 are indicative of these sentiments: "Many consumers who shop at discount stores may be unaware that their right to buy at the lowest price possible is under siege. . . Today, retailers who are cut off-or threatened with termination-by a manufacturer because they failed to raise prices, have little recourse under the law."170 Although economic theory in and of itself may not dictate a rule of per se illegality for RPM, there is a widespread belief that there are other, noneconomic values that should be vindicated by the Sherman Act. ${ }^{171}$ Many observers argue that the Chicago School approach is incompatible with the pursuit of these goals. ${ }^{172}$

Second, the free-rider paradigm is neither methodologically airtight nor intuitively appealing in all cases. ${ }^{173}$ For example, not all retailers provide visible point-of-sale services to consumers. ${ }^{174}$ For consumers to be able to consciously free ride on a retailer's

170137 CoNG. REC. $\$ 1933$ (daily ed. Feb. 20, 1991).

${ }^{171}$ Commonly mentioned "non-economic" concerns include wealth distribution, the fostering of small businesses, intrabrand competition, and "independent business people" autonomy. See Burns, supra note 167, at 598 n.6. For other articles advocating the use of antitrust policy in fostering these goals, see Louis B. Schwartz, "Justice" and Other Non-Economic Goals of Antitrust, 127 U. PA. L. REv. 1076, 1081 (1979) ("Recognition of the non-economic goals of antitrust warrants a pro-antitrust resolution of controversies over the ... desirability of breaking up persistent monopolies even if no 'predatory' actions can be proved.") and Lawrence A. Sullivan, Antitrust, Microeconomics, and Politics: Reflections on Some Recent Relationships, $68 \mathrm{CAL}$. L. REV. 1, 11 (1980) (noting that "static price theorists" would object to "any public intervention aimed at preserving" small business and arguing that "political action preserving [these markets], even at some cost, might result in a net increase in welfare").

${ }^{172}$ See, e.g., Burns, supra note 167, at 617 ("[T] he economic efficiency approach has eliminated from the antitrust calculus all consideration of the various [noneconomic] concerns ..... .).

${ }^{173}$ See Terry R. Weiss, The Dealer-Services Rationale for Resale Price Maintenance: Does the Manufacturer Really Know Best?, 30 ST. LouIS U. L.J. 517, 525-34 (1986) (arguing that "[t]he dealer-services explanation for [RPM] is methodologically flawed" because it is "cast within the framework of a perfectly competitive market" structure).

${ }^{174}$ The response of Robert Pitofsky to a New York Times editorial which supported RPM is illustrative: "Most products on which resale price maintenance has been attempted-blue jeans, drugs, cosmetics, men's underwear and others-require little or no retail services in the first place." Robert Pitofsky, The Service Fallacy, N.Y. TIMES, Apr. 18, 1991, at A24. According to Pitofsky, the free-rider explanation for RPM is an "elegant but unsupported theory developed by conservatives in the halls of academia." Id. Not all researchers are skeptical of the free-rider hypothesis, however. See, e.g., Pauline M. Ippolito, Resale Price Maintenance: Economic Evidence from Litigation, $34 \mathrm{~J}$. LAW \& ECON. 263, 283 (1991) (contending that retailer free riding explained as much as $65 \%$ of the studied occurrences of RPM). 
provision of services, the services must be apparent to the consumer. ${ }^{175}$ The services must also be separable from the particular product involved. ${ }^{176}$ Furthermore, retailers must be better able to provide the service than the manufacturer. ${ }^{177}$ Finally, characteristics of the consumers who ultimately purchase a good can affect how much benefit a RPM program provides. ${ }^{178}$

These criticisms of the free-rider justification of RPM provide guidance to those seeking to justify RPM through transaction cost economics. First, it must not be forgotten that antitrust law has concerns other than economic efficiency. A transaction cost justification of RPM will not gain widespread acceptance if it ignores the populist underpinnings of the antitrust law. Secondly, the Chicago School encountered resistance because it attempted to provide an overarching theory to explain the use of RPM in all cases. A justification for RPM will be more likely to gain accep-

175 Such services have been categorized in the literature as visible or "tangible" dealer services. See Howard P. Marvel \& Stephen McCafferty, Resale Price Maintenance and Quality Certification, 15 RAND J. ECON. 346, 347 (1984).

${ }^{176}$ If the services are not separable from the product, the consumer cannot take advantage of them without purchasing the product from the primary retailer. Thus, retailer services such as generous return, maintenance, and repair policies are usually not susceptible to free riding. See generally Timothy Greening, Analysis of the Impact of the Florsheim Shoe Case, in IMPACT EvaluatIons OF FEDERAL TRADE COMMISSION VERTICAL RESTRAINTS CASES 91, 154 (Ronald N. Lafferty et al. eds., 1984) (noting that in the footwear industry, " $\mathrm{t}] \mathrm{he}$ most important services, inventory and ambience [particularly fitting areas], are apparently immune to free-riding").

${ }^{177}$ For a discussion of situations in which this state of affairs is likely to exist, see Marvel \& McCafferty, supra note 175 , at 347 ( $[$ [F]ree-riding is a problem for manufacturers so long as consumers care where a product is sold but do not care where [the retailers] purchase[d] their ... supplies of the good."). See also G.F. Mathewson \& R.A. Winter, The Incentives for Resale Price Maintenance Under Imperfect Information, 21 ECON. INQUIRY 337, 339 n.6 (1983) ("If national brand-advertising were a perfect substitute for [point of sale information,] then the incentive for [RPM] would disappear.").

${ }^{178}$ Most likely, only certain consumers will value the extra services provided by retailers. For example, as consumers become more familiar with a product or its technology, the market, as a whole, places less value on the services. The obvious policy implication is that, ceteris paribus, RPM for more established products is likely to be less beneficial to consumers. See, e.g., William S. Comanor, Vertical Price-Fixing, Vertical Market Restrictions, and the New Antitrust Policy, 98 HARv. L. REv. 983, 990 (1985) (arguing that " $[t]$ he conventional wisdom [behind the free-rider hypothesis] fails to acknowledge the importance of differences among consumers regarding their preferences for dealer provided services"). There are some exceptions to this proposition. For instance, consumers may value services relating to some established products, especially if the products are purchased infrequently, such as archery equipment or automobiles. 
tance, however, if the scenarios to which it is applicable are clearly defined and intelligently limited.

\section{A TRANSACTION-COST-BASED JUSTIFICATION FOR RPM}

Before Kodak Co. v. Image Technical Services, Inc., ${ }^{179}$ a court's use of a transaction-cost-economics theory to justify RPM would have been unthinkable, especially in light of the Chicago School's failure to produce significant judicial acceptance of vertical price restraints. Recent developments, however, have made such a justification more likely to be well received by the courts. This Part first discusses Kodak, which opened the door for the use of transaction cost economics in antitrust analysis, and then looks at a transaction-cost-economics justification for the use of RPM.

\section{A. Kodak}

\section{The Decision}

The Kodak decision and its lower court history have been dissected and analyzed at length. ${ }^{180}$ This Comment, therefore, limits discussion of the facts of the case to those necessary to facilitate an understanding of the methodology used by the Supreme Court in reaching its decision.

Defendant-petitioner, the Eastman Kodak Company (Kodak), manufactures and markets high volume photocopiers and micrographic equipment. Kodak also manufactures and markets replacement parts for its machines and sells service contracts for the machines. The plaintiffs-respondents are independent service organizations (ISOs) that compete with Kodak in the market for service contracts. ${ }^{181}$ The Supreme Court adopted the finding of the court below that Kodak did not possess a large share of the

179112 S. Ct. at 2072, 2085 (1992).

${ }^{180}$ See generally Jacobs, supra note 4, at 339 (reviewing "the role assigned by the Kodak court to informational failures in the determination of market power"); Spivack \& Ellis, supra note 3, at 203-04 (examining the significance of Kodak for development of antitrust law); Lisa M. Judson, Note, Kodak v. Image Technical Services: The Taming of Matsushita and the Chicago School, 1993 WIS. L. REv. 1633, 1636 (concluding that "Kodak embodies a firm rejection of the Chicago School as the principal source of antitrust policy").

${ }^{181}$ See 112 S. Ct. at 2076. 
equipment market. ${ }^{182}$ Kodak did, however, possess an overwhelmingly large share of the markets for service contracts and parts. ${ }^{183}$

Until 1985, Kodak and the ISOs had an uneasy coexistence. Beginning in 1985, Kodak instituted a policy of refusing to sell replacement parts to buyers of Kodak equipment who did not use Kodak servicers for service or repair of their machines. ${ }^{184}$ Kodak also maneuvered to limit ISO access to parts and used machines. ${ }^{185}$ As a result of these practices, many ISOs went out of business or lost money. ${ }^{186}$ The ISOs filed suit in 1987 , alleging that Kodak monopolized and attempted to monopolize the service market for Kodak machines ${ }^{187}$ and that Kodak illegally tied the sale of parts to the sale of service contracts. ${ }^{188}$ After very limited discovery, the district court granted Kodak's motion for summary

${ }^{182}$ See id. at 2081 n.10.

${ }^{183}$ Kodak possessed $80 \%$ to $95 \%$ of the service market and almost $100 \%$ of the parts market. See id. at 2077, 2090. Kodak did not manufacture all of the parts itself; some were manufactured by independent original-equipment manufacturers. See id. at 2077. Other sources of Kodak parts included (1) brokers who had purchased parts from Kodak, (2) customers who had bought parts from Kodak, and (3) used equipment stripped for parts. See id. at 2077 n.2.

${ }^{184}$ See $i d$. at 2077.

185 See id. at 2078.

186 See id.

${ }^{187}$ See id. Both monopolization and attempted monopolization violate the Sherman Act. See 15 U.S.C. \$ 2 ("[E]very person who shall monopolize, or attempt to monopolize, ... shall be deemed guilty of a felony .... . ).

${ }^{188} \mathrm{See} \mathrm{Kodak,112} \mathrm{S.} \mathrm{Ct.} \mathrm{at} 2078$. A tie-in or tying agreement is an arrangement by which a manufacturer conditions the sale of one product (the tying product) upon the buyer's purchase of another good (the tied-in product). See Siegel v. Chicken Delight, Inc., 448 F.2d 43, 47 (9th Cir. 1971) (holding that while defendant's contractual requirements constituted a tying arrangement in violation of the Sherman Act, fact issues remained whether damage had resulted), cert. denied, 405 U.S. 955 (1972). A tying agreement is illegal under $\$ 1$ of the Sherman Act if "the tying product possesses sufficient economic power appreciably to restrain competition in the tied product market," and the tying affects a "not insubstantial" amount of commerce. Id. (citation omitted). Tying arrangements may also violate the Clayton Act. See 15 U.S.C. $\$ 14$ (1988) (establishing that it shall be unlawful for any person engaged in commerce to make a sale or contract for commodities on the condition that the purchaser shall not use or deal in the goods of a competitor where the effect may be to substantially lessen competition or tend to create a monopoly). Only the Sherman Act test applied to the arrangements at issue in Kodak, however, because the Supreme .Court had previously held that the Clayton Act's prohibition does not apply to tying arrangements in service markets. See Times-Picayune Pub. Co. v. United States, 345 U.S. 594, 609-10 (1953) (holding that "[w]hile the Clayton Act's more specific standards illuminate the public policy which the Sherman Act was designed to subserve, ... the Government here must measure up to the criteria of the more stringent law"). 
judgment. ${ }^{189}$ The Ninth Circuit reversed, ${ }^{190}$ and Kodak appealed.

In discussing Kodak's arguments for summary judgment, the majority ${ }^{191}$ noted that Kodak did not "present any actual data on the equipment, service, or parts markets. Instead, it urge[d] the adoption of a substantive legal rule that 'equipment competition precludes any finding of monopoly power in derivative aftermarkets.'"192 The majority, however, rejected Kodak's argument, invoking the principle that "[1]egal presumptions that rest on formalistic distinctions rather than actual market realities are generally disfavored in antitrust law. ${ }^{\text {193 }}$

The Court first took pains to explain the holding in Matsushita: "The Court's requirement in Matsushita that the plaintiffs' claims make economic sense did not introduce a special burden on plaintiffs facing summary judgment in antitrust cases. . . . Matsushita demands only that the nonmoving party's inferences be reasonable in order to reach the jury ...."194 The Court then distinguished Kodak's situation from that in Matsushita on the ground that the plaintiffs' inferences, that Kodak did indeed have market power in the aftermarkets, were reasonable in the face of "evidence of increased prices and excluded competition [in the aftermarkets]." 195

${ }^{189}$ Kodak moved for summary judgment before discovery had begun. The district court allowed the plaintiffs 30 interrogatories, 6 depositions, and 22 requests for production of documents. See Judson, supra note 180, at $1665 \mathrm{n} .200$ (discussing Kodak's procedural history from the inception of the suit to the district court's grant of summary judgment five months later).

${ }^{190}$ See Image Technical Serv., Inc. v. Eastman Kodak Co., 903 F.2d 612 (9th Gir. 1990).

${ }^{191}$ Justice Blackmun wrote the opinion, in which Chief Justice Rehnquist and Justices White, Stevens, Kennedy, and Souter joined. Justice Scalia wrote the dissenting opinion, in which Justices O'Connor and Thomas joined.

${ }^{192}$ Kodak, 112 S. Ct. at 2082 . In making this argument, Kodak relied in large part on Matsushita. Kodak's contention was that it was highly implausible, according to Chicago School analysis, that it could exercise market power in the aftermarkets for parts and services without having equipment market power. See id.; see also Ward S. Bowman, Jr., Tying Arrangements and the Leverage Problem, 67 YALE L.J. 19, 20 (1957) (arguing that a manufacturer without significant market share in the primary market cannot gain leverage or market power in an aftermarket through the use of a tying arrangement). Therefore, Kodak argued, Matsushita counseled the Court to grant summary judgment to Kodak. See Kodak, 112 S. Ct. at 2082.

193112 S. Ct. at 2082.

${ }^{194} I d$. at 2083.

195 Id. 
The Kodak Court purported to prefer the resolution of antitrust issues "on a case-by-case basis, focusing on the 'particular facts disclosed by the record." 196 More specifically, the Court noted that " $[r]$ espondents offer a forceful reason why Kodak's theory, although perhaps intuitively appealing, may not accurately explain the behavior of the primary and derivative markets for complex durable goods: the existence of significant information and switching costs. ${ }^{197}$ The Court pointed to evidence that suggested that many of Kodak's customers could not always ascertain the true life-cycle cost of the total equipment, service, and parts package prior to purchase. ${ }^{198}$ Furthermore, consumers who became dissatisfied with Kodak's package after purchase were "locked-in" to the Kodak package by the comparatively high cost of changing brands. ${ }^{199}$

\section{Implications for the Use of Transaction Cost Economics}

The Kodak Court, in looking beyond the assumptions of the Chicago School to the economic reality of the situation, utilized transaction cost methodology. The information costs and switching costs referred to by the majority appear to be nothing more than the embodiment, in varying degrees, of bounded rationality, uncertainty, opportunism, and asset specificity. ${ }^{200}$ In addition, the Kodak majority used articles analyzing monopolistically competitive markets to form and explain its conclusions. ${ }^{201}$ For example, the Court relied on Steven Salop's characterization of the imperfections operative in monopolistically competitive markets to explain why information about the cost attributes of Kodak equipment might not permeate the equipment market. ${ }^{202}$

${ }^{196}$ Id. at 2082 (quoting Maple Flooring Mfrs. Ass'n v. United States, 268 U.S. 563 , 579 (1925)).

${ }^{197}$ Id. at 2085.

198 See id.

${ }^{199}$ See id. at 2087.

${ }^{200}$ See supra notes 134-39 and accompanying text (defining and discussing these problems).

201 The Court's discussion of market behavior in terms of a monopolistically competitive model implies a willingness to discard a number of neoclassical assumptions including the lack of barriers to market entry, the existence of perfect information, and the rationality of market participants. See supra part II.A for a discussion of the Chicago School approach.

${ }^{202}$ See 112 S. Ct. at 2087 n.22 (citing Steve Salop, Information and Market StructureInformation and Monopolistic Competition, AM. ECON. REv., May 1976, at 240). The Court also cited Steven Salop \& Joseph Stiglitz, Bargains and Ripoffs: A Model of 
Not only did the Court embrace the transaction cost economics paradigm, but the majority opinion also moved away from the approaches advocated by the Chicago School. Most significantly, the Court rejected a strict reliance on market share as an indicator of market power. ${ }^{203}$ Market power has been defined, somewhat murkily, in Supreme Court cases as the ability "to set higher than competitive prices." ${ }^{204}$ The Kodak Court defined market power, however, as "the power 'to force a purchaser to do something that he would not do in a competitive market." ${ }^{205}$ Market power is an important concept in antitrust jurisprudence because it is a key variable in the application of the rule of reason test. In the 1980s, market share was increasingly used to cut antitrust proceedings short, as courts consistently refused to find market power in the absence of significant market share. ${ }^{206}$ In Kodak, however, the Court used transaction cost arguments to find that Kodak could have market power in the aftermarkets in the absence of market share in the primary market. ${ }^{207}$

The theoretical approach employed by the Kodak majority allowed the Court to become more involved with specific factual

Monopolistically Competitive Price Dispersion, 44 REv. EcoN. STud. 493, 508 (1977) (predicting that monopolistically competitive conditions would produce price dispersion even if the products involved are identical), and George J. Stigler, The Economics of Information, 69 J. POL. EcON. 213, 214 (1961) (arguing that "it would be ... fruitless, to assert that all [price] dispersion is due to heterogeneity"). See id.

${ }^{203}$ See id. The Supreme Court has consistently held that although raw market share is an imperfect measure of market power, practicality and ease of computation favor its use in calculating market power. See, e.g., United States v. Grinnell Corp., 384 U.S. 563, 571 (1966) (holding that a company with an $87 \%$ share of a defined market has market power); United States v. E.I. duPont de Nemours \&c Co., 351 U.S. 377,389 (1956) (holding that a party has monopoly power if it has the ability to control prices or restrict competition).

${ }^{204}$ Matsushita Elec. Indus. Co. v. Zenith Radio Corp., 475 U.S. 574, 590 (1986).

205112 S. Ct. at 2080 (quoting Jefferson Parish Hosp. Dist. v. Hyde, 466 U.S. 2, 14 (1984)). The Kodak Court also accepted another definition of market power as "the ability of a single seller to raise price and restrict output." Id. at 2081 (quoting Fortner Enter., Inc. v. United States Steel Corp., 394 U.S. 495, 503 (1969)).

${ }_{206}$ See, e.g., Thomas E. Kauper, Antitrust in 1992: The Year of the Storyteller, 61 ANTITRUST L.J. 347, 349-50 (1993) (arguing that "market power screens . . . have repeatedly precluded plaintiffs from telling their 'story').

${ }^{207} \mathrm{See} 112 \mathrm{~S}$. Ct. at 2084 . Some commentators are fearful of the administrative ramifications of Kodak for the rule of reason test. See, e.g., Jacobs, supra note 4, at 348-49 (predicting that the Kodak Court's use of transaction cost arguments to infer aftermarket power on Kodak's part “threatens to disrupt thoroughly the course of antitrust law, burdening the lower courts with a slew of difficult problems, and hopelessly confusing the business community about the boundaries of antitrust enforcement"). 
inquiries into the workings of the relevant markets. ${ }^{208}$ As a consequence of its newfound recognition of informational deficiencies and the theory of monopolistic competition, the Kodak Court relied upon anecdotal evidence offered by the plaintiffs and allowed the plaintiffs to survive summary judgment by virtue of "storytelling. ${ }^{209}$ As a result of Kodak, trial courts now have Supreme Court precedent for guidance in focusing on how elements of imperfect information and uncertainty, operating in a monopolistically competitive environment, can affect the results predicted by standard economic models. ${ }^{210}$ Future litigants now have some hope that courts will be receptive to the use of a "new" paradigm in antitrust which in turn would allow the courts to apply a rule of reason test. ${ }^{211}$

${ }^{208}$ Much of the commentary on Kodak has focused on the fact-based aspects of the methodology employed by the Kodak Court, as opposed to the a priori arguments employed by the Chicago School and relied upon by the Kodak Company. See Stephen Calkins, Supreme Court Antitrust 1991-92: The Revenge of the Amici, 61 ANTITRUST L.J. 269, 307 (1993) (noting that " [t] he Court was distinctly uncomfortable with the kind of a priori" reasoning commonly used by the Chicago School); see also Kauper, supra note 206, at 349 (noting that "[a]s the 1980s passed, the certainty of the per se rules of the 1960 s came to be replaced by a new, more sophisticated certainty based on price theory and economic models").

${ }^{209}$ See Kauper, supra note 206, at 348 (noting that prior to the Kodak decision and throughout the 1980s, "putative storytellers ... found that their attempts to put the whole factual story on the record were frustrated by reliance on economic models"). By way of contrast, the Kodak Court appeared "to have been significantly influenced by a number of amicus briefs filed in support of plaintiffs by states and their purchasing officials, and by other groups of users." Id. at 355 n.47. "These amici asserted that they as users would be better off without such [tying arrangements] . . ." Id. at $355-56$ n.47.

${ }^{210}$ The extent to which the Court recognized the impact of information costs, for the purposes of antitrust analysis, was surprising to most observers and disturbing to some. "For although lack of information and consumer myopia surely may be encountered in some markets, one would least expect to find them in markets for sophisticated business equipment." Kattan, supra note 2, at 23. Kattan points out that "[i]f the ability to make rational decisions cannot be ascribed to businesses considering the purchase of sophisticated business equipment, it can hardly be ascribed to ordinary consumers considering the purchase of washing machines or automobiles." Id.

${ }^{211}$ Kauper describes the history of antitrust as shaped in large part by a "tension between the search for simple rules-rules which are easily understood by the business community and readily administrable by courts-and the need [honored in Kodak] for the careful examination of all of the factual variations and nuances each case presents, the story of the case." Kauper, supra note 206, at 347. The "new" fact intensive antitrust approach displayed in Kodak is actually closer to the traditional legal reasoning used by courts in other areas of the law than to the approach more recently taken by the courts in antitrust. See generally Flynn \& Ponsoldt, supra note 167 , at 1128-29 (discussing the divergence of recent antitrust jurisprudence from the 


\section{B. A Transaction Cost Economics Justification for RPM}

Currently, courts conceptualize RPM cases in terms of the cartel paradigm. ${ }^{212}$ The use of this paradigm naturally led courts to view RPM agreements as deserving of per se treatment. Before courts will consider applying a rule of reason test to RPM programs, they must be persuaded to view RPM through the lens of a different paradigm. Once made aware of the reality that manufacturers may have procompetitive reasons for using RPM and that RPM may have beneficial effects on relevant markets, courts may reconsider their position that RPM agreements are lacking in "any redeeming virtue." 213

The following discussion will demonstrate that transaction cost economics provides a convenient analytical framework for bringing about this judicial reconsideration. This Part will set forth a justification for RPM as used by manufacturers attempting to enter a market with a new product. The argument utilizes the same transaction cost methodology employed in the Kodak decision. In addition, the market entrant justification is situated to take advantage of some of the traditional concerns of antitrust.

\section{The Market Entry Scenario}

Potential market entrants ${ }^{214}$ typically find it more difficult to enter a market successfully than the theory of perfect competition predicts. ${ }^{215}$ The market entrant's difficulties primarily involve transaction costs. More specifically, transaction costs arise when a manufacturer introduces a new product or product line and when a manufacturer attempts to ensure that the correct level of service and support is being provided to consumers. These transaction costs and the ways by which RPM can help manufacturers overcome them will be discussed in turn.

fact-finding approach traditionally employed by courts).

212 The cartel enforcement paradigm governs vertical price restraints, see generally supra part I, and to a certain extent the free-rider paradigm governs nonprice vertical restraints. See Baker, supra note 112, at 1467 (noting the Sylvania Court's use of the free-rider theory, which was originally developed for vertical price restraints, to justify the nonprice vertical restraints used by the GTE Sylvania Company).

213 Northern Pac. Ry. Co. v. United States, 356 U.S. 1, 5 (1958).

${ }^{214}$ In terms of size, potential market entrants can range from tiny "start-up" companies with virtually no name recognition to well-known companies that are developing new product lines and exploring new market segments.

215 For a discussion of the assumptions of perfect competition, see supra notes 106 10 and accompanying text. 


\section{a. Introducing a New Product or Product Line}

\section{i. Potential Barriers to Entry}

A manufacturer introducing a new product or product line may face a number of potential barriers to entry that are generated by transaction costs. First, even though consumers may be comfortable with the kind of technology involved, they may view the new entrant's product with suspicion, especially when the product's quality cannot be ascertained through visual inspection. This problem is exacerbated in the case of complex durable goods because, in terms of quality assessment, technical expertise beyond the capacity of the consumer may be required. Further, durable goods, such as cars or computers, are generally purchased infrequently. This prevents buyers from developing the sophisticated purchasing skills that come from repeat experience. Second, the new entrant's problem is worsened by the fact that manufacturer advertising is relatively less effective for new products and littleknown brands. ${ }^{216}$ Third, a potential market entrant faces the inertia of brand loyalty which may prevent consumers from switching to new brands. ${ }^{217}$ Fourth, consumer mistrust, occasioned by bounded rationality and opportunism, can constitute a formidable barrier to entry.

In other situations, even though the market entrant may enjoy some measure of brand recognition, its downstream retailers may have little credibility in the eyes of buyers, who are wary of "fly-bynight" retailers who skimp on service. Skimping on service to unwary customers may become profitable for certain retailers because the retailer can consistently reap short-run profits by exaggerating product quality to consumers. Such retailers know

${ }^{216}$ See Phillip Nelson, Advertising as Information, 82 J. POL. ECON. 729, 732 (1974) (discussing how consumers are more likely to be swayed by advertising as their familiarity with a good increases).

${ }^{217}$ Common marketing wisdom distinguishes between "shopping" and "specialty" goods. Specialty goods are those for which buyers have built up considerable loyalty and habitual buying patterns and for which the buyer exerts little in-store decisionmaking effort. See Greening, supra note 176, at 97. Shopping goods, on the other hand, have less consumer loyalty and consumers exert substantial in-store decisionmaking effort. See id. at 96 (noting that consumers purchase shopping goods infrequently and thus tend to spend "considerable" time and effort before deciding to spend their money). By definition, buyer inertia is higher for specialty goods. Also, for goods involving a substantial investment, buyers are more likely to be risk averse in their purchase behavior, opting to remain with familiar brands. 
that the reputational effects from such dishonesty will affect the manufacturer only in the long run. ${ }^{218}$ Viewed in terms of game theory, consumers may be unwilling to risk dealing with unknown or suspicious-looking dealers, even if doing so means saving money, because the "winning" strategy for the retailer may be to skimp on service. ${ }^{219}$

The literature has documented the increased costs market entrants must incur to develop brand recognition and overcome consumer mistrust. Commentators regard these expenditures as an initial investment necessary to develop a good reputation, which will yield a premium in later periods. ${ }^{220}$ These expenses signal to consumers the intentions of the manufacturer (or other market participant) to deliver expected, required, or advertised quality. Included in this category of costs are items such as testimonials by celebrity spokespersons, uniforms for salespersons, and expensive renovations to buildings, such as signs, lights, and the like.

\section{ii. How RPM Can Help}

In such situations, RPM can help potential market entrants erode barriers to entry. A manufacturer targeting an upscale market niche may well be willing to "pay" a higher-end retailer to carry its products because of the positive marketing impact that associating its goods with the retailer's name will have on sales. This type of "service," provided by retailers to manufacturers, is not the tangible point-of-sale service usually envisioned by proponents of the free-rider hypothesis. These less tangible services have been referred to as "quality certification" in the literature. ${ }^{221}$ Consum-

${ }^{218}$ See Carl Shapiro, Premiums for High Quality Products as Returns to Reputations, Q.J. ECON. 659, 660 (1983) (" $[I] n$ markets with reputations, sellers can always increase profits in the short-run by reducing the quality of their products. After all, quality reductions will yield immediate cost savings, while the adverse effect on reputation will arise only in the longer run."). Perhaps the most publicized example of this phenomenon has occurred in the market for used cars. See George A. Akerlof, The Market for "Lemons": Quality Uncertainty and the Market Mechanism, 84 Q.J. ECON. 488, $488(1970)$ (noting that in the market for lemons "there is incentive for sellers to market poor quality merchandise, since the returns for good quality accrue to [the industry as a whole] rather than to the individual seller").

${ }^{219}$ See supra part II.B.1.c (discussing game theory).

${ }^{220}$ See Shapiro, supra note 218, at 660 . As would be expected, Shapiro's work indicates that the intensity and duration of the reputational effect will usually be positively correlated with the size of the reputation investment. See id. at 668-69 (noting that, in markets for high-quality goods, large investments in reputation are generally followed by large amounts of subsequent profits).

${ }^{221}$ See Marvel \& McCafferty, supra note 175, at 358 (noting one manufacturer's 
ers perceive the retailer as making an implicit representation that the product is of the same quality as other goods carried by the retailer. ${ }^{222}$ Consequently, certification services can both introduce the product to a skeptical market and establish the product as belonging to a certain quality category. In this way an RPM program helps the market entrant establish brand identity and differentiate its product from those of its competitors. ${ }^{223}$ In some cases RPM allows the manufacturer to use the price of the good itself as an important marketing tool. ${ }^{224}$

The higher margin allowed by RPM assures the high-end retailer that the manufacturer will compensate it for reserving shelf space for the manufacturer's products. ${ }^{225}$ Further, in situations where

desire to sell its goods "in leading stores" not so much to obtain special services, but rather "to secure from them certification of the long-lasting ... qualities" of its products).

${ }^{222}$ See, e.g., Victor P. Goldberg, The Free Rider Problem, Imperfect Pricing, and the Economics of Retailing Services, 79 Nw. U. L. REV. 736, 744 (1984) ("By carrying a product, the retailer provides an endorsement that can be valuable. Instead of paying an ex-athlete to say 'I like it[.]' . . . the manufacturer can pay Macy's to say 'I like it enough to stock it." ).

${ }^{223}$ As discussed supra note 109 and accompanying text, the concept of product differentiation is foreign to the model of perfect competition. The neoclassical economist views advertising aimed at creating product differentiation as wasteful. See, e.g., BYRNS \& STONE, supra note 106, at 219, 221 (criticizing advertising that misleads consumers into perceiving illusory product differences). Monopolistic competition theorists, however, take a different view of product differentiation. See infra notes 256-61 and accompanying text (discussing how RPM can counteract the tendency for suboptimal product diversity, leading to increased social welfare).

${ }^{224}$ See Greening, supra note 176, at 138-44 (explaining the importance of quality signals such as price). The Florsheim Shoe Company viewed the final retail price of its shoes as an important part of its efforts to differentiate its shoes from those of competitors and appeal to its target market. See id. at 137.

${ }^{225}$ In such a situation, the manufacturer's task is to reduce the effect that the potential for opportunism has on its relationship with retailers. An RPM program ensures high-end retailers that they will appropriate the entire benefit derived from their certification services. Otherwise, an opportunistic manufacturer could use highend retailers to "advertise" its product while simultaneously selling to lower-end dealers. The margin allowed by RPM represents the manufacturer's "commitment" to the high-end retailers. See, e.g., Goldberg, supra note 222, at 736 (outlining the free-rider problem for retailers offering services such as advice and demonstrations). In other situations, manufacturers may want to avoid lower-end retailers completely, fearing that such lower-end retailers may "blur" the quality signal. See Stigler, supra note 202, at 224 ("The [high-end] department store ... searches for the superior qualities of goods and guarantees that they are good quality. [Such stores] may be explicable chiefly as devices for eliminating uncertainties in quality."). In this scenario high-end retailers have little need to fear manufacturer opportunism because the manufacturer's aim is to lower consumers' perceived information costs in obtaining its goods. See id. at 223-24 (noting that search costs are costs of purchase that manufacturers seek to reduce). 
consumers are suspicious of the particular retailers distributing the manufacturer's product, the higher retail margins allowed by RPM can serve to finance expenditures by retailers. These expenditures can help to reassure customers of retailers' integrity. ${ }^{226}$

Finally, with regard to a court's analysis of an RPM program in this scenario, it is true that complex durable goods usually generate higher transaction costs for both manufacturers and consumers, and thus present easier cases for upholding RPM arrangements. ${ }^{227}$ Also, RPM programs involving complex durable goods can draw the most support from Kodak because of their similarities to the facts in that case. ${ }^{228}$ When determining the desirability of an RPM arrangement, however, courts should also consider the familiarity of the market with the good involved, regardless of the good's apparent noncomplexity. ${ }^{229}$ Consumer mistrust may create entry barriers for manufacturers of goods at various levels of complexity and durability.

${ }^{226}$ For example, such expenditures allow consumers to differentiate between the car dealer operating out of a bare lot decorated with strings of orange plastic triangles and the car dealer operating out of a well-maintained physical plant, complete with signs bearing the manufacturer's name.

${ }_{227}$ This is so because complex durable goods are more likely to involve new technology or new applications of existing technology. Consumers, besides being unfamiliar with the brand name involved, are unfamiliar with how the product functions. Thus, the market entrant in markets for complex durable goods may face multiple levels of consumer uncertainty.

${ }^{228}$ See supra notes 180-85 and accompanying text (discussing the products and markets involved in the Kodak case).

${ }^{229}$ A study of the FTC enforcement proceedings against Levi Strauss demonstrated that the market's familiarity with a noncomplex consumer good could impact the desirability of an RPM program. See Oster, supra note 162 . From 1850 through the mid-1940s, the Levi Strauss Company sold primarily work clothes. After World War II, however, Levi Strauss gradually changed its emphasis from work clothes to casual wear. See id. at 67-68. By the 1960s, as part of its efforts to develop a high-quality reputation for its new lines of casual wear, Levi Strauss was attempting "to hold prices up to preserve retail margins as a way to induce high quality retailers to stock their goods." Id. at 65 . Obviously, blue jeans are not complex durable goods. Because of the need to introduce consumers to its new lines of casual wear, however, Levi Strauss found RPM useful for quality signaling and increasing sales for a significant period of time. Oster found that as the market became familiar with Levi Strauss's new product lines, RPM began to have a detrimental effect on jean sales. "[A]s the market became saturated with Levi's jeans, the gains from restrictions to signal quality would naturally fall." Id. at 68 . Over time, "brand identification of Levi Strauss made rpm as a quality signal less useful." Id. at 70-71. 


\section{b. Enforcement of Service and Support Contracts}

\section{i. Potential Transaction Costs}

Beyond the transaction costs market entrants face in introducing their products to the market, the market entrant must also be concerned about the costs associated with enforcing its service and support contracts with retailers. ${ }^{230}$ In this regard, the interests of the manufacturer and its retailers do not always coincide, and the retailers may have strong incentives not to honor their various commitments to the manufacturer. ${ }^{231}$

For example, retailers may perceive that, due to the presence of advertising externalities or "spillovers," full benefits of their sales efforts. If there are many consumers with low search $\operatorname{costs}^{233}$ in the market, retailers providing high levels of service may lose out if such low-search-cost consumers take advantage of the retailer's services but then buy the product from a discounter. ${ }^{234}$ Consequently, in order to avoid losses, the highend retailers provide fewer services than the manufacturer desires. Conversely, because of the low-search-cost consumers, low-end retailers gain the benefit of high-end retailers' efforts. ${ }^{235}$ Given this positive externality, low-end retailers also may severely cut back on service. The market-wide result is that retailers as a whole do not produce enough information to maximize sales. ${ }^{236}$ Experience

${ }^{230}$ The manufacturer's contracts with retailers may obligate the retailers to provide tangible, point-of-sale services, quality certification services, or other services that fit into neither category. See, e.g., Klein \& Murphy, supra note 27, at 281-82 (discussing how a beer manufacturer desired retailers to provide services not apparent to the consumer, but nevertheless essential to the quality of the product, such as adequate refrigeration and stock rotation).

${ }^{231}$ See supra note 225 (discussing the free-rider problem that discourages high-end retailers from providing certification services). Manufacturers, of course, attempt to maximize profit from market-wide sales. A retailer's concern is much more narrow: profit maximization at its individual retail outlet. These goals may not be compatible and may add another layer of transaction costs for market entrants to face.

${ }^{232}$ See G.F. Mathewson \& R.A. Winter, An Economic Theory of Vertical Restraints, 15 RAND J. ECON. 27, 31 (1984) (discussing "spillovers" or externalities of the benefits of advertising among retailers).

${ }^{233}$ An example of a low-search-cost consumer is one who does not mind running from store to store in search of the lowest price in the area.

${ }^{234}$ See Mathewson \& Winter, supra note 232, at 31 (noting that retailers fail to "appropriate the full benefit of their own advertising" in such situations).

${ }_{235}$ See id. (noting that retailers share in the benefits of the advertising of other retail competitors due to spillovers).

${ }^{236}$ See id. at 33 (summarizing, in tabular form, the impacts of advertising spillovers and other externalities on retailer advertising expenditures). In the case of a 
has also shown that manufacturers may have more to worry about than the mere under provision of services by retailers due to these externalities because retailers may take more active steps to divert customers from a manufacturer's product. ${ }^{237}$

\section{ii. How RPM Can Aid the Market Entrant}

Although it is usually easy for the manufacturer to specify the retailer's obligations in service and support contracts in writing, ensuring that the retailer is in fact adhering to the obligations is often costly. This is especially true since the possible cost savings encourage retailers to cheat on a contract. The manufacturer's objective is to minimize its monitoring costs while simultaneously maximizing the probability that the retailer honors the contract. Consequently, the manufacturer-retailer relationship takes on the characteristics of a game in which the participants weigh the costs and benefits of various cheating and compliance strategies. ${ }^{238}$

RPM can assist manufacturers in ensuring that retailers adhere to their contractual duties. RPM provides a premium stream to the retailer. This stream is the retailer's "reward" for adhering to the contract, which will be foregone if the retailer cheats and is subsequently terminated and/or sued for damages. The retailer's gain from cheating is saving the cost of providing the extra services. When a retailer's perceived gain from cheating becomes less than the retailer's gain from adherence, the contract becomes "selfenforcing." 239 Although the manufacturer must still commit some

franchisor-franchisee relationship, these externalities may be especially severe. The franchisor is concerned that an opportunistic franchisee will take advantage of the franchisor's reputation and decrease service quality, thereby reaping extra short-run profits. Customers will be drawn in by the brand name's reputation, but, as a result of the poor service, will adopt an unfavorable view of the franchisor's product, hurting other franchise outlets. See Benjamin Klein, Transaction Cost Determinants of "Unfair" Contractual Arrangements, AM. ECON. REV., May 1980, at 356, 358-59 (describing the incentive of opportunistic franchisees to supply lower quality products than required under their contracts with the franchisor).

${ }^{237}$ For instance, some retailers use the manufacturer's name to draw customers into the store, but then direct customers to similarly priced "no-name" brands on which the retailer earns a higher margin. This tactic is commonly known as the "bait and switch." See, e.g., Goldberg, supra note 222, at 745 (explaining the appeal of the "bait and switch" to retailers); Howard P. Marvel, Exclusive Dealing, 25 J.L. \& ECON. 1, 6-8 (1982) (describing the fears of manufacturers regarding "bait-and-switch" practices); see also infra note 261 (describing "bait-and-switch" practices used by large discounters against an electronics manufacturer).

${ }^{238}$ See supra part III.B.I.c (discussing game theory).

${ }^{299}$ For an extended theoretical discussion of the dynamics of contract enforcement 
resources to monitoring performance, ${ }^{240}$ given the appropriate cost conditions, RPM can help the manufacturer realize cost savings. ${ }^{241}$ By giving the retailer a "reward" for adhering to its contract, the higher retail margins allowed by RPM serve to align the manufacturer's and individual retailer's interests.

\section{The Market Entrant Justification and the Goals of Antitrust}

The preceding section has shown how RPM can alleviate some transaction cost problems encountered by market entrants. While the Kodak Court's use of transaction cost analysis will lend substantial support for the expansion of the methodology, this factor alone probably will not suffice to bring widespread acceptance of the market entrant justification. In order to succeed, the market entrant justification, like the free-rider hypothesis, must address and meet the traditional concerns of antitrust. ${ }^{242}$

For many years, two key goals of antitrust have been the promotion of consumer welfare ${ }^{243}$ and the protection of "economic freedom," which equates roughly to the ability of smaller market participants to survive and develop uncoerced by larger economic entities. ${ }^{244}$ During periods of heightened antitrust activity, enforcing bodies were unified and driven by a world view that "linked high concentration in markets ... with lessened competition ... [and

in this context, see Benjamin Klein \& Keith B. Leffler, The Role of Market Forces in Assuring Contractual Performance, 89 J. POL. ECON. 615, 618-25 (1981) (noting that a "firm will honor its implicit quality contract as long as the difference between the capital values of the noncheating and cheating strategies ... is positive").

${ }^{240}$ See, e.g., Lester G. Telser, Why Should Manufacturers Want Fair Trade II?, 33 J.L. \& ECON. 409, 411 (1990) (discussing a manufacturer's monitoring requirements in the context of a perishable product).

${ }^{241}$ This phenomenon provides an answer to critics who ask why manufacturers cannot simply require services by contract. See Abrams, supra note 166, at A24 (arguing that manufacturers should pursue "legal ways" to require retailers to provide services, rather than impose RPM). These critics miss the point that, given the presence of externalities and transaction costs, contracts may be too costly to enforce in the absence of some device that aligns the interests of the manufacturer with the retailer.

242 See supra notes $169-72$ and accompanying text (discussing the free-rider hypothesis and its failure to address the noneconomic goals of antitrust).

${ }^{243}$ Courts currently judge the overall competitive merit of a course of conduct in terms of its effect on the ultimate consumers who will purchase the product. See, e.g., Jefferson Parish Hosp. Dist. No. 2 v. Hyde, 466 U.S. 2, 15 (1984) (noting that, ultimately, the intended beneficiaries of antitrust laws are consumers). This emphasis is a direct consequence of the influence of economics and the Chicago School in antitrust.

${ }^{244}$ See supra note 171 (discussing generally the noneconomic goals of antitrust). 
asserted that when a few large firms dominate markets] small and aspiring sellers as well as the citizens of our political democracy are worse off." 245

Nothing in the Kodak opinion implies that the Court has discarded these goals, as the decision strongly emphasized that the record disclosed both increased prices and excluded competition. ${ }^{246}$ The Court's discussion, in part, examined the ways in which the transaction costs and information deficiencies of the relevant markets could have enabled Kodak to raise the effective cost of its equipment, services, and parts package to consumers. ${ }^{247}$ The Court's opinion also showed obvious concern for the smaller market participants who had allegedly been crushed under the weight of Kodak's conduct. ${ }^{248}$ Consequently, an analysis of the effects of RPM, relative to these two goals, is essential to an assessment of the likelihood that the courts will accept the market entrant justification. In addition, a litigant using Kodak and the market entrant justification in defense of her RPM program should realize that she must answer the standard pre-Kodak questions about the arrangement's empirical effects on these goals. ${ }^{249}$

\section{a. Consumer Welfare Effects}

RPM can help to increase consumer welfare in at least two ways. First, to the extent that it induces the provision of more information and/or services, an RPM program increases the value of products to consumers. Admittedly, RPM usually raises the average price for a good above that which would be observed in the absence of the arrangement. ${ }^{250}$ Various critics have seized upon this phenome-

${ }^{245}$ Fox \& Sullivan, supra note 104, at 942 (citations omitted).

246 "The alleged conduct-higher service prices and market foreclosure-is facially anticompetitive and exactly the harm that antitrust laws aim to prevent." Kodak, 112 S. Ct. at 2088.

${ }^{247}$ See id. at 2086-87 (finding that Kodak could have discriminated in pricing between sophisticated and unsophisticated customers to take advantage of the customers' high cost of information gathering).

${ }^{248} \mathrm{See}$ id. at 2090-92 (noting that Kodak would have violated antitrust law if it "adapted its parts and service policies as part of a scheme of willful acquisition or maintenance of monopoly power").

${ }^{249}$ Although the Kodak plaintiffs' evidence was described as "folksy" and "anecdot[al]" by various observers and litigation participants, this evidence did address itself to the twin concerns of consumer welfare and excluded competition. Calkins, supra note 208, at 307 .

${ }^{250}$ By definition, RPM eliminates discounters, which has the effect of raising average prices. 
non in condemning RPM. ${ }^{251}$ To the extent that the price-maintained product is sold with more information or services, however, it may constitute a different or more valuable product for the purposes of consumer welfare analysis. If the information and sale services provided by retailers as a result of RPM are valued by consumers, the new product, information, and services package will support a higher price than will the bare product alone. ${ }^{252}$ The theoretical work done on RPM suggests that it can increase consumer welfare in situations where the majority of consumers in the market have relatively high search costs or place a high value on additional services or information. ${ }^{253}$

Transaction cost economists have repeatedly emphasized that information is a valuable commodity in the marketplace, and that

${ }^{251} \mathrm{See}$ Bowman, supra note 28 , at 850 (suggesting that, "it is reasonable to expect that [the] use of [RPM] would make for higher consumer prices"). Bowman discusses the results of a study, conducted from January 1, 1951 through January 31, 1953, examining the differences in prices for toothpaste in fair-trade and non-fair-trade states. See id. at 852-55. The study found higher prices in fair-trade states than in non-fair-trade states, and higher prices in rural areas, generally. See id. at 856; see also F.M. SCHERER, INDUSTRIAL MARKET STRUCTURE AND ECONOMIC PERFORMANCE 593 (2d ed. 1980) (citing a 1956 Justice Department survey that "revealed that the prices of 132 widely fair-traded products were 19 percent lower than the fair trade minimum ... in eight cities not bound by r.p.m. laws"); B.S. Yamey, Introduction: The Main Economic Issues, in ReSALE PRICE MAINTENANCE 1, 4 (B.S. Yamey ed., 1966) (arguing that RPM "obstructs the process of price competition ... [thereby keeping] resale prices higher than they would otherwise be").

${ }^{252}$ See, e.g., Comanor, supra note 178, at $988-90$ (noting that both lawyers and economists tend to believe that manufacturers will impose RPM only when the value of the added information and services outweighs the increase in product price).

${ }^{253}$ See, e.g., Mathewson \& Winter, supra note 177, at 343-44. Mathewson and Winter's work assumes that some consumers incur high search costs in making purchasing decisions, and thus cannot afford to go from store to store in search of the lowest price. See id. at 340 . Other consumers incur low search costs. See id. (assuming in their model that consumers must either have prohibitively high search costs or zero search costs). By simultaneously inducing high-end retailers to provide more information and services and by eliminating some discounting outlets, RPM affects these two consumer groups differently. The high-search-cost consumers clearly benefit because each high-end retailer provides enough services and information to meet the needs of such consumers. This eliminates the need for high-search cost buyers to search for the services they require. The low-search-cost consumers may suffer because they lose the opportunity to purchase products at a lower cost from the discounters. The overall welfare effect depends on the quantity of extra services induced by RPM and on the composition of the consumer market. See id. at 343-44 (analyzing the welfare effects of RPM on these kinds of consumers). This result is also predicted by Comanor, supra note 178, at 990-92 (noting that information services supplied through vertical restraints "may be oversupplied in relation to the consumer optimum," depending on the information needs of all consumers in the market). 
market participants usually cannot gain information without substantial cost. ${ }^{254}$ For its part, the Kodak Court implicitly recognized the value of information in the market; the decision reveals that the Court was impressed by how valuable accurate information is to consumers in various equipment markets and after-markets. ${ }^{255}$ The Kodak Court's recognition of the value of information in the marketplace suggests a realization that prices are not the dispositive variable in the calculus of consumer welfare and the analysis of the desirability of a market restraint.

Aside from its potential to increase the total amount of information available in the market, RPM can increase consumer welfare by optimizing product diversity. A transaction cost methodology, utilizing concepts of monopolistic competition, is needed to advance this product diversity argument; the theory of perfect competition places little emphasis on the benefits of product differentiation. ${ }^{256}$

The normal operation of monopolistically competitive markets $^{257}$ may result in less than optimal product diversity. This systemic tendency toward suboptimal amounts of product diversity arises in large part as a result of the presence of fixed costs, as "fixed costs restrict the number and variety of products that it is feasible . . . to supply. ... [They] force an economy to choose from the large set of all conceivable products. . . Products that survive are those that are capable of generating revenues sufficient to cover

${ }^{254}$ See, e.g., Salop \& Stiglitz, supra note 202, at 494 (outlining an economic model in which "informed [customers] must gather costly information to obtain the lower price"); Stigler, supra note 202, at 213 (describing that a buyer-or seller-who wishes to find the most favorable price must canvass or search for various sellers or buyers).

255 See Kodak, 112 S. Ct. at 2085-87 (noting, for example, that for the service market price to affect equipment demand, consumers must inform themselves of the total cost of the "package"-equipment, service, and parts-at the time of the purchase).

${ }^{256}$ The father of the theory of monopolistic competition, Edward Hastings Chamberlin, viewed the state of affairs envisioned by perfect competition, i.e., perfect product homogeneity, as potentially undesirable. See CHAMBERLIN, supra note 140, at 214 ("Differences in tastes, desires, incomes, and locations of buyers, and differences in the uses which [buyers] wish to make of commodities all indicate the need for variety. ..."). Since this pronouncement, more mathematically rigorous theoretical works have reinforced Chamberlin's intuitions. See Michael Spence, Product Selection, Fixed Costs, and Monopolistic Competition, 43 REv. ECON. STUD. 217, 217 (1976) ("Fixed costs . . . restrict the number and variety of products that . . is feasible or desirable to supply.").

257 "Normal operation" in this sense includes the absence of vertical price restraints. 
the fixed and variable costs." ${ }^{258}$ If fixed costs are high enough, and the demand for a good is sufficiently small, manufacturers will be unable to sell enough of the good to bring per-unit costs down to an acceptable level. ${ }^{259}$

Both the theoretical and empirical work in this area suggest that "high-end" products are the most prone to being squeezed out of the market by cost conditions since these products are the least likely to have broad-based demand. ${ }^{260}$ This tendency toward suboptimal product diversity can affect even the largest firms. ${ }^{261}$ RPM offers a solution to this problem by inducing retailers to provide the desired services-whether tangible or otherwise-thereby expanding sales sufficiently to ensure production of the high-end products. This could have positive welfare implications, as socially

${ }^{258}$ Spence, supra note 256 , at 217.

259 "[B]ecause revenues do not capture the consumer surplus, revenues may not cover costs even when the social value of the product is positive." Id. at 220. Spence adds that " $[\mathrm{n}] \mathrm{o}$ one, I think, would argue that revenues are an accurate measure of the social benefits of a product." Id. at 217; see also Martin K. Perry \& Robert H. Groff, Resale Price Maintenance and Forward Integration into a Monopolistically Competitive Industry, 100 Q.J. ECON. 1293, 1302-09 (1985) (discussing the effect of various assumptions concerning the structure of the market on equilibrium levels of product diversity).

${ }^{260}$ This phenomenon can be due to both high fixed costs and advertising externalities. The presence of the externalities means that retailers will not realize the full benefit of their service efforts. As a result, retailers will reduce their services accordingly, and sales will suffer. The decline in sales may be sufficient to drive a particular good out of production. See, e.g., William A. McEachern \& Anthony A. Romeo, Vertical Restraints in the Audio Components Industry: An Economic Analysis of FTC Intervention, in IMPACT EVALUATIONS OF FEDERAL TRADE COMMISSION VERTICAL RESTRAINTS CASES 200, 231 (Ronald N. Lafferty et al. eds., 1984) (discussing how the prevalence of free riding, combined with the inability of the manufacturer to use RPM as a solution, put severe strains on at least one manufacturer, Pioneer, servicing the high-price segments of the audio components market).

${ }^{261}$ Even large manufacturers possessing significant market shares are fighting pressures from discounters to eliminate high-end products. The recent experience of RCA is indicative of this trend. When large discounters, such as " $\mathrm{K}$-mart, Wal-Mart Stores Inc. and Circuit City Stores Inc. demanded to do business directly with RCA, the manufacturer gambled it could overcome the lower margins with higher sales." Dana Milbank, Consumer-Goods Makers, Growing Wary of Big Chains, Try to Forge Small Links, WALL ST.J., June 24, 1991, at B1, B7. RCA soon ran into problems, however, as "[b]ig dealers demanded ever-lower prices and refused to push RCA's new high-end products. ... Worse, the chains used the bait-and-switch technique to lure consumers to similarly priced no-name brands to enlarge their own margins." Id. The experience of RCA reveals that the large discounters actively discouraged RCA's attempts to manufacture high-end products. "We became subservient to the retailers,' says Jack Sauter, RCA's former marketing head. 'They would say, "Just build the product and give me the right price." $I d$. 
valued high-end products that would not get produced absent RPM would become profitable for manufacturers.

\section{b. RPM and Economic Freedom}

With regard to the second area of concern in Kodak, economic freedom, RPM fares better than one might expect. First, RPM may be less harmful to small business owners than previous public discussion indicates. Specifically, empirical work has shown that RPM allows smaller retailers to remain in the market, ceteris paribus. ${ }^{262}$ This result may also be desirable from the manufacturer's standpoint, especially where the demand for its product is positively correlated to the number of retail outlets carrying the product. $^{263}$ As expected, the desirability and likelihood of a proliferation of smaller retailers depend on the prevailing cost conditions, because products with broad-based demand are not likely to benefit from RPM. ${ }^{264}$ Thus, RPM has some potential for negating the currently existing forces tending to eliminate smaller dealers from the retail market. ${ }^{265}$ Also, to the extent that RPM

262 See, e.g., Marvel \& McCafferty, supra note 175, at 356-57 (explaining that at least one study indicates that RPM “does indeed preserve smaller retailers in the drug store market"). The authors cite a comprehensive study, conducted in 1963, which revealed that retailer size was greater in non-RPM states than in states which permit RPM. See id. (focusing on "whether r.p.m. affects the size of retailers").

${ }^{263}$ This demand condition is known as the "outlets hypothesis." See J.R. Gould \& L.E. Preston, Resale Price Maintenance and Retail Outlets, 32 ECONOMICA 302, 303 (1965) ("The 'outlets hypothesis': final demand for the manufacturer's product is a function of both its price and the number of retailers."). The outlets hypothesis may be more likely to explain demand for a product whose consumers have high search costs. These consumers will be less willing to travel long distances from outlet to outlet in search of services; they may even want assurances that the services will be provided at every retail outlet.

264 Generally, assuming that an RPM program produces higher retail margins and prices, retailers will tend to sell fewer units per retail outlet. See id. at 304 ("Marginal cost would be above marginal revenue . . . and profit maximization would suggest a reduction in scale."). In the case of products for which retailers enjoy considerable economies of scale, an RPM arrangement would be neither stable nor desirable. See id. at 309 (arguing that "[c]onditions favourable to r.p.m." require that "economies of scale in retailing should be present but not too marked"). Consequently, an RPM arrangement is most likely to be desirable for specialty and high-end products which do not enjoy large broad-based consumer demand.

${ }^{265}$ Recent trends in retailing have made survival extremely difficult for smaller retailers competing with large discount chains. Unlike the smaller retailers, each chain outlet is able to benefit from cost advantages gained by virtue of the total size of the retail chain. See, e.g., Milbank, supra note 261, at B7 (discussing how large retail chains demanded special price concessions on motor oil from the Quaker State Corporation); Linda Wilson, Automatic Replenishment-Middlemen Fight Back, 
increases product diversity, it can work against foreclosure in the manufacturing sector by allowing manufacturers of "niche" products to enter and remain in the market. ${ }^{266}$ To the extent that these franchise fees are substantial, the fees may constitute formidable barriers to entry.

The economics literature has also identified ways in which the imposition of RPM is less restrictive on market entry than non-price restraints. ${ }^{267}$ This theoretical work casts doubt on some observers' contentions that RPM represents a greater "restraint on trade" than other currently legal vertical restrictions. ${ }^{268}$ For example, the use of exclusive territories and exclusive dealership agreements, two varieties of nonprice vertical restrictions, can create significant barriers to entry because dealers are unable to carry the products of the potential entrants for the duration of their contracts with the manufacturer. ${ }^{269}$ RPM, conversely, does not contractually limit either the number of retailers or the number of brands sold in a geographic region. From the retailer's perspective, then, RPM may constitute much less of a restraint. Another commonly encountered vertical restraint, the franchise fee, used by some manufacturers in an attempt to appropriate a greater portion of their brand name goodwill, requires additional up-front investment from retailers desiring to enter the market. ${ }^{270}$

INFORMATIONWEEK, Oct. 12, 1992, at 36, 37 (discussing Wal-Mart's use of its market share to force manufacturers to deal directly with Wal-Mart, which provides cost savings not available to smaller retailers).

${ }^{266}$ See supra notes $256-57$ and accompanying text (discussing the effects of RPM on product diversity and market foreclosure).

${ }_{267}$ See, e.g., Baxter, supra note 42, at 935 (noting that "surely neither [RPM] is so bad, nor other forms of vertical restrictions so benign, as to justify the sharp categorical differences in their present legal status").

${ }_{268}^{26}$ Abrams, supra note 166, at A24 (condemning RPM).

${ }^{269}$ This reality has not been lost on antitrust scholars. "To forbid a dealer or distributor to sell outside of its territory, when it is the only distributor or dealer of the manufacturer's brand in the territory, has, if anything, a greater adverse effect on intrabrand competition ... ." Posner, supra note 158, at 9; see also McEachern \& Romeo, supra note 260, at 221-22 (noting that exclusive dealing arrangements may have the effect of inhibiting entry because the potential entrants at the manufacturing level would have a choice of establishing new retailers or bidding away retailers committed to existing manufacturers); Tim R. Sass \& Michael Gisser, Agency Cost, Firm Size, and Exclusive Dealing, 32 J.L. \& ECON. 381, 381 (1989) (noting that "[s]ome have viewed [exclusive dealing contracts] as an attempt to erect barriers to entry").

270 "As an empirical matter, franchisees pay ex ante fixed franchise fees at the time of contract signing. Such fees represent a nonrefundable commitment ...." G. Frank Mathewson \& Ralph A. Winter, The Economics of Franchise Contracts, 28 J.L. \& ECON. 503, 516-17 (1985). 
In the context of the market entry analysis, RPM is wellpositioned in terms of the populist concerns of antitrust. ${ }^{271}$ It can both increase consumer welfare and promote "economic freedom" in the markets.

\section{Potential RoAdblocks to the ACceptance of THE Market ENTRANT JUSTIFICATION OF RPM: POLITICAL, JURISPRUDENTIAL, AND ECONOMIC FACTORS}

Despite the availability of the market entry justification for RPM, it is by no means certain that courts will utilize it. Regardless of the theoretical appeal of the transaction cost approach, there are other factors that influence the justification's prospects for acceptance. The following discussion explores these factors.

As an initial matter, there are questions concerning Kodak's value as precedent. Observers have noted that, due to the sparse nature of the record before the Court in Kodak, the case "will almost always be distinguishable." ${ }^{272}$ For example, Kodak could be strictly limited to its facts and confined to cases involving tie-ins or markets for complex durable goods. ${ }^{273}$ Furthermore, the Kodak case was before the Supreme Court on a summary judgment motion, with very little discovery completed. As such, Kodak's value as precedent might be limited to a clarification of the summary judgment standard in antitrust. ${ }^{274}$ Nonetheless, the Supreme Court indicated that, given the appropriate evidentiary showing, the plaintiffs' argument could have won the case. Thus, many commentators are rather hopeful that, after Kodak, "the post-Chicago School has the opportunity to advance. Plaintiffs can at least attempt to prove their information-based allegations." 275

${ }^{271}$ These concerns are always near the forefront of congressional consciousness. In the end, populist concerns for the "little guy" may be more instrumental in securing a rule of reason treatment for RPM arrangements than the more theoretically based consumer welfare arguments. See infra notes 277-84 and accompanying text (discussing the lobbying efforts of small businesses during the consideration of RPM legislation).

${ }^{272}$ Calkins, supra note 208, at 297.

${ }^{273}$ See Jacobs, supra note 4, at 369 ("Lower courts could decide, for example, that Kodak's methodology for determining market power should apply only to markets for 'complex durable goods,' and only to those markets demonstrating the same kind of information imperfections and switching costs discussed in Kodak.").

${ }^{274}$ See id. at 337 (quoting Justice Blackmun, who felt that Kodak concerned nothing more than "the standard for summary judgment in an antitrust controversy").

${ }^{275}$ Lande, supra note 10 , at 197. 
Another obstacle to the acceptance of the market entry justification for RPM relates to Congress's historical wariness towards such schemes. Given the Supreme Court's reluctance to openly defy the will of Congress and to embrace RPM, change in congressional attitudes may need to occur before courts will extend Kodak in the manner suggested by this Comment. ${ }^{276}$

Such change, however, is not altogether unlikely, especially considering recent developments in the economic and political climate. As large-scale discount retailers grow in size and influence, groups with adverse economic interests are likely to clamor for the application of closer antitrust scrutiny of these retail giants. ${ }^{277}$ In fact, during the latest attempt to codify the rule of Dr. Miles Medical Co. v. John D. Park $\mathcal{E}^{2}$ Sons Co., ${ }^{278}$ small businesses were nearly successful in attaching a small retailer exception to the bill. ${ }^{279}$ The main opposition to Senate Bill 429 centered around the

${ }^{276}$ Congressional hostility toward RPM has been a significant impediment to the courts' adoption of a rule of reason standard in the area of vertical price restraints. See supra note 68 and accompanying text (discussing the Sylvania Court's interpretation of the significance of the repeal of the Miller-Tydings Enabling Act). For a contrary argument, however, see Michael Boudin, Antitrust Doctrine and the Sway of Metaphor, 75 GEO. L.J. 395, 421 (1986) (claiming that "the general prescription for judges and lawyers alike is vigilance, coupled with an understanding of the ways of metaphor in legal argument," thereby suggesting that the pressure to change the law on RPM must come from a judiciary persuaded by theoretical or academic arguments).

${ }^{277}$ For example, Wal-Mart, the largest American retailer, is facing a rising tide of hostility. The megaretailer is currently defending itself against charges of predatory pricing in an action commenced in 1992 by independent drug stores in Arkansas. See Wendy Zellner, Not Everybody Loves Wal-Mart's Low Prices, BuS. WK., Oct. 12, 1992, at 36. The suit is being brought under state law. See id.; see also Southland Violated Laws, Breached Pacts, Franchisee Suit Says, WALL ST. J., Aug. 27, 1993, at B10 (reporting a suit brought by 7-Eleven convenience store franchisees which alleges that the Southland Corporation conspired with Wal-Mart Stores Inc.'s McLane Company distribution unit to divide wholesale markets as well as other antitrust violations); Wilson, supra note 265, at 36-37 (reporting on the lobbying efforts of independent manufacturers' sales representatives to induce FTC investigation of Wal-Mart's push to bypass the representatives and deal directly with the suppliers of products).

278220 U.S. 373 (1911). For a discussion of Dr. Miles Medical and the per se rule against RPM, see supra part I.A.1.

${ }^{279}$ The House version of the anti-RPM bill, H.R. 1470, contained an amendment written by Representative Thomas J. Campbell that would have exempted small businesses from the relaxed evidentiary requirements imposed on larger manufacturers. See 63 ANTITRUST \& TRADE REg. REP. (BNA) No. 1572, at 3 (July 2, 1992). The Campbell amendment was not a part of the version of the bill presented to the House for final approval. See id. Concerns about the definition of "small business" prevented the Campbell amendment from becoming part of the bill presented to, and defeated by, the House. See id. 
concern that it would be "too potent a weapon in the hands of large discounters." ${ }^{280}$ The National Federation of Independent Businesses (NFIB) expressed concern that the proposed law would tip "the scales against small Main Street business owners in favor of large discounters at a time when discounters do not appear to be suffering in the marketplace." 281

Furthermore, current congressional attitudes appear to be based upon outdated conceptions of the American economic scene. For example, Senator Howard Metzenbaum, in his promotion of the 1991 Consumer Protection Against Price-Fixing Act, painted a picture of a "down and out" discounting sector, claiming that "[t]oday we are presented again with the prospect of a market subject to fair trade laws." 282 Given the present strength of the low-end retailing sector, however, such concerns appear misplaced. ${ }^{283}$ If and when congressional leaders acknowledge the true state of the retailing sector, RPM should garner more congressional tolerance.

Thus, if the congressional debate on the subject reveals enough support for reconsideration of the per se rule against RPM, an adventuresome court, building upon the Kodak decision, may seize the opportunity to reexamine Dr. Miles Medical. Furthermore, as the economic pressure on smaller market participants mounts, it is even possible that future legislative lobbying efforts by these groups will succeed in gaining exemptions of varying scope from the per se ban on RPM. ${ }^{284}$

${ }^{280} I d$.

${ }^{281}$ Id. (quoting NFIB president John F. Motley).

282137 CONG. REC. S2006 (daily ed. Feb. 20, 1991) (statement of Sen. Metzenbaum).

${ }^{283}$ The available empirical evidence suggests that even in its heyday, RPM did not affect a large portion of the retail markets. See SCHERER, supra note 251, at 594 ( ${ }^{\text {The }}$ value of fair-traded items fell from an estimated 10 percent of retail sales in 1959 to 4 percent in 1974.").

284 Such exemptions are not unheard of in antitrust. For example, professional baseball enjoys a complete exemption from antitrust regulation. See, e.g., Thane N. Rosenbaum, The Antitrust Implications of Professional Sports Leagues Revisited: Emerging Trends in the Modern Era, 41 U. MIAMI L. REV. 729, 767 (1987) ("Baseball has escaped antitrust liability since 1920 , when Justice Holmes wrote for a unanimous Court in Federal Baseball Club of Baltimore, Inc. v. National League of Professional Baseball Clubs." ). In the context of RPM, these exemptions could include a full-fledged reversal of $D$ r. Miles Medical, a provision for rule of reason treatment for RPM programs instituted by "small" manufacturers, or simply stiffer evidentiary requirements for proving the existence of illegal RPM programs. 


\section{CONCLUSION}

This Comment has attempted to predict the impact of the Kodak decision on courts' future treatment of RPM. As a result of the Kodak decision, future courts have support for using transaction cost economics, rather than the cartel explanation, in determining whether an RPM program violates the Sherman Act. Building on a transaction cost methodology, this Comment has set forth the market entry scenario as a justification that is especially likely to gain the courts' approval. An analysis of the scenario revealed that RPM can have a procompetitive effect on relevant markets. The market entry justification also coincides with the historical goals of antitrust law. Finally, it was conceded that there are some uncertainties as to what value future courts will give to the Kodak decision as precedent, and that substantial congressional opposition to RPM still remains.

History reveals that the law has taken varying positions on RPM, never remaining frozen in place. Antitrust policies are built upon economic theories that are no stronger than their weakest assumptions. As such, these theories are vulnerable to changes in the economic, political, and commercial landscape. ${ }^{285}$ As a consequence of Kodak's recognition of the frailties of abstract theory, RPM may one day experience a resurgence.

${ }^{285}$ See Herbert Hovenkamp, Antitrust Policy After Chicago, 84 MiCH. L. REv. 213, 215 (1985) (comparing differing antitrust economic theories to competing scientific models in that each has a readily discernible life cycle); see also THE POLITICAL ECONOMY OF THE SHERMAN ACT: THE FIRST ONE HUNDREd YEARS 3 (E. Thomas Sullivan ed., 1991) (examining both the legislative intent of the Sherman Act and the political economy that informed the legislation, and analyzing the contemporary debates concerning the goals and values that underlay the Act); Judson, supra note 180 , at 1639 ("Antitrust has continually changed course to accommodate certain economic and political ideologies, and most every political generation has abandoned the ideas and policies of its predecessors in favor of something new."). 


\section{.}

